\title{
Source apportionment of submicron organic aerosol at an urban background and a road site in Barcelona (Spain) during SAPUSS
}

\author{
M. Alier ${ }^{1}$, B. L. van Drooge ${ }^{1}$, M. Dall'Osto ${ }^{1, *}$, X. Querol ${ }^{1}$, J. O. Grimalt ${ }^{1}$, and R. Tauler ${ }^{1}$ \\ ${ }^{1}$ Department of Environmental Chemistry, Institute of Environmental Assessment and Water Research (IDAEA-CSIC), \\ C/Jordi Girona, 18-26, 08034, Barcelona, Catalonia, Spain \\ *now at: Institut de Ciències del Mar (ICM-CSIC), Pg. Marítim de la Barceloneta 37-49, 08003 Barcelona, Spain
}

Correspondence to: B. L. van Drooge (barend.vandrooge@idaea.csic.es)

Received: 8 March 2013 - Published in Atmos. Chem. Phys. Discuss.: 24 April 2013

Revised: 10 September 2013 - Accepted: 12 September 2013 - Published: 24 October 2013

\begin{abstract}
This study investigates the contribution of potential sources to the submicron $\left(\mathrm{PM}_{1}\right)$ organic aerosol $(\mathrm{OA})$ simultaneously detected at an urban background (UB) and a road site (RS) in Barcelona during the 30 days of the intensive field campaign of SAPUSS (Solving Aerosol Problems by Using Synergistic Strategies, September-October 2010). A total of 103 filters at $12 \mathrm{~h}$ sampling time resolution were collected at both sites. Thirty-six neutral and polar organic compounds of known emission sources and photo-chemical transformation processes were analyzed by gas chromatography-mass spectrometry (GC-MS). The concentrations of the trace chemical compounds analyzed are herein presented and discussed.

Additionally, OA source apportionment was performed by multivariate curve resolution-alternating least squares (MCR-ALS) and six OA components were identified at both sites: two were of primary anthropogenic OA origin and three of secondary OA origin, while a sixth one was not clearly defined. Primary organics from emissions of local anthropogenic activities (urban primary organic aerosol, or POA Urban), mainly traffic emissions but also cigarette smoke, contributed $43 \%\left(1.5 \mu \mathrm{g} \mathrm{OC} \mathrm{m}^{-3}\right)$ and $18 \%$ $\left(0.4 \mu \mathrm{g} \mathrm{OC} \mathrm{m}^{-3}\right)$ to $\mathrm{OA}$ at $\mathrm{RS}$ and $\mathrm{UB}$, respectively. A secondary primary source - biomass burning (BBOA) - was found in all the samples (average values $7 \% \mathrm{RS} ; 12 \% \mathrm{UB}$; $0.3 \mu \mathrm{g} \mathrm{OC} \mathrm{m}{ }^{-3}$ ), but this component was substantially contributing to OA only when the sampling sites were under influence of regional air mass circulation (REG.). Three secondary organic aerosol (SOA) components (describing overall $60 \%$ of the variance) were observed in the urban ambient $\mathrm{PM}_{1}$. Products of isoprene oxidation (SOA ISO) - i.e.
\end{abstract}

2-methylglyceric acid, $\mathrm{C}_{5}$ alkene triols and 2-methyltetrols - showed the highest abundance at both sites when the city was under influence of inland air masses. The overall concentrations of SOA ISO were similar at both sites $(0.4$ and $0.3 \mu \mathrm{g} \mathrm{m}^{-3}$, or $16 \%$ and $7 \%$, at UB and RS, respectively). By contrast, a SOA biogenic component attributed to $\alpha$-pinene oxidation (SOA BIO PIN) presented average concentrations of $0.5 \mu \mathrm{g} \mathrm{m}^{-3}$ at UB (24\% of OA) and $0.2 \mu \mathrm{g} \mathrm{m}^{-3}$ at RS (7\%), respectively, suggesting that this SOA component did not impact the two monitoring sites at the same level. A clear anti-correlation was observed between SOA ISO and SOA PIN during nucleation days, surprisingly suggesting that some of the growth of urban freshly nucleating particles may be driven by biogenic $\alpha$-pinene oxidation products but inhibited by isoprene organic compounds. A third SOA component was formed by a mixture of aged anthropogenic and biogenic secondary organic compounds (SOA Aged) that accumulated under stagnant atmospheric conditions, contributing for $12 \%$ to $\mathrm{OA}$ at $\mathrm{RS}\left(0.4 \mu \mathrm{g} \mathrm{OC} \mathrm{m}^{-3}\right)$ and for $18 \%$ at $\mathrm{UB}\left(0.4 \mu \mathrm{g} \mathrm{OC} \mathrm{m}{ }^{-3}\right)$.

A sixth component, formed by $\mathrm{C}_{7}-\mathrm{C}_{9}$ dicarboxylic acids and detected especially during daytime, was called "urban oxygenated organic aerosol" (OOA Urban) due to its high abundance at urban RS $\left(23 \% ; 0.8 \mu \mathrm{g} \mathrm{OCm}^{-3}\right)$ vs. UB $(10 \%$; $0.2 \mu \mathrm{g} \mathrm{OCm}^{-3}$ ), with a well-defined daytime maximum. This temporal trend and geographical differentiation suggests that local anthropogenic sources were determining this component. However, the changes of these organic molecules were also influenced by the air mass trajectories, indicating that atmospheric conditions have an influence on this component, although the specific origin on this component remains 
unclear. It points to a secondary organic component driven by primary urban sources including cooking and traffic (mainly gasoline) activities.

\section{Introduction}

Atmospheric aerosols' influence on the atmospheric visibility (Watson, 2002) is relevant in climate forcing (Forster et al., 2007) and has several adverse effects on human health (Brunekreef et al., 2005). They contain a significant and variable fraction of organic material, ranging from $20 \%$ to $90 \%$ of the submicron $(<1, \mu \mathrm{m}$ in particle size $)$ particulate matter $\left(\mathrm{PM}_{1}\right)$ mass (Kanakidou et al., 2005). Such organic material divides into two broad categories termed primary and secondary. Primary organic aerosols (POA) in urban areas are emitted from combustion sources, including heavyand light-duty vehicles, wood smoke, cooking activities, industries and others. Such primary particles can be modified in the presence of various atmospheric oxidants, such as $\mathrm{OH}$ radical, $\mathrm{O}_{3}$ and $\mathrm{NO}_{\mathrm{x}}$, (Donahue et al., 2009), yielding more oxygenated products that change their original physicochemical properties. By contrast, secondary organic aerosols (SOA) are formed from reactions of both anthropogenic and biogenic volatile organic compounds (VOC). They are mainly composed of oxygenated organic species (Hallquist et al., 2009). Overall, the knowledge about sources, fate and mutual interaction of gas phase and aerosol organics of which it is estimated that there are between 10000 and 100000 different compounds - is still limited (Schauer et al., 2007; Goldstein and Galbally, 2007; Bi et al., 2008). Particularly, the composition and behaviour of SOA in the atmosphere are not completely well known. For example, several studies showed that diluted emissions from diesel emissions or biomass burning produce large quantities of SOA (Grieshop et al., 2009; Sage et al., 2008), while other field measurements showed the enhanced formation of SOA from gasoline emissions over diesel emissions (Bahreini et al., 2012).

Such complexity of the atmospheric aerosol system is pushing the development of measurement techniques and instrumentation (Pratt and Prather, 2012). In this regard, the aerosol mass spectrometer (AMS) has recently revolutionized the field of atmospheric science because it allows chemical speciation, sizing and mass detection of submicron nonrefractory PM at high time resolution (Canagaratna et al., 2007). This technique has demonstrated that a large part of the organic aerosol is highly oxidized and probably formed by SOA (Jimenez et al., 2009; Kanakidou et al., 2005). Recently, a lot of emphasis has been put on the importance of cooking activities for ambient air quality (Allan et al., 2010; Mohr et al., 2012).

However, a main disadvantage of such on-line technique is the limited organic aerosol speciation provided (Pratt and
Prather, 2012). By contrast, the combination of off-line filter techniques in combination with gas chromatography-mass spectrometry (GC-MS) allows a wider organic compound speciation, although covering a very small fraction (often $<5 \%$ ) of the organic aerosol mass detected. However, the relatively small number of tracer compounds analyzed can be used as input for chemometric methods with the aim to re-construct the emissions from different sources of atmospheric components (Schauer et al., 2007; Stone et al., 2009). The number of existing source apportionment techniques applied on off-line filter data is relatively large, including principal component analysis (PCA; Jollife, 2002), chemical mass balance (CMB; US-EPA, 1987) and positive matrix factorization (PMF; Paatero and Tapper, 1994). PCA uses orthogonal constraints, and environmental interpretation of score and loading profiles is sometimes cumbersome. CMB requires the previous knowledge of the emission source profiles, and therefore it is unable to identify unknown sources. PMF integrates natural constraints like non-negativity and uncertainty estimations in a rigorous non-linear optimization of the distribution and composition source profiles. In this work we deploy the multivariate curve resolutionalternating least squares (MCR-ALS) method (Tauler et al., 1995; Tauler, 1995; Jaumot et al., 2005) that has previously been applied for environmental source apportionment (Salau et al., 1997; Terrado et al., 2009). MCR-ALS is based on an alternating linear least squares optimization under nonnegativity constraints which produces physically better profiles than PCA, and it has been shown to produce analogous results to PMF (Tauler et al., 2009; Staminirova et al., 2011).

The objective of this study is to characterize the $\mathrm{PM}_{1}$ organic aerosol component sampled during the SAPUSS intensive field study conducted in Barcelona (Spain) during the period September-October 2010. This manuscript is part of the SAPUSS special issue (Dall'Osto et al., 2013b). The current study is unique in regards of a large data set of more than $100 \mathrm{PM}_{1}$ filters collected simultaneously at an urban background site (UB) and an urban road site (RS). The urban study area of Barcelona has some unique features. It is characterized by one of the highest density of vehicles in Europe as well as a densely populated city center. Moreover, its geographical position (western Mediterranean basin) favors photo-chemical reactions and accumulation of secondary aerosols (Querol et al., 2009; Perez et al., 2010; Pey et al., 2009).

Past studies at an urban background site in Barcelona (same UB location used in this SAPUSS study) showed that a large fraction $(56 \%)$ of the OA consisted of oxygenated OA (Mohr et al., 2012). Moreover, radioactive carbon analysis showed that about $60 \%$ of the organic carbonaceous atmospheric matter in this background site has a non-fossil origin (Minguillón et al., 2011). However, there is evidence that biomass burning contributes only a small part $(\sim 15 \%)$ of the urban background OA, which is mainly related to the winter season or wild fire events (Mohr et al., 2012; Reche 
et al., 2012; van Drooge et al., 2012a). This gives way to the hypothesis that other non-fossil sources should account for an important part of the OA. Indeed, Mohr et al. (2012) attributed $17 \%$ of the OA to primary food cooking emissions after AMS analysis in the UB site. Nevertheless, there is still a lack of information upon the chemical speciation of this source. Furthermore, the contribution of different types of SOA of both anthropogenic and biogenic origins is still highly uncertain in the urban area of Barcelona.

In summary, the simultaneous analysis of selected organic tracer compounds analyzed from the $\mathrm{PM}_{1}$ filter samples collected at the UB and at the RS sites is herein presented. Furthermore, a source apportionment of the OA is also carried out and discussed.

\section{Materials and methods}

\subsection{Sampling sites}

Detailed information on the urban sites studied in Barcelona is given elsewhere (Dall'Osto et al., 2013b). The urban background site (UB; $41^{\circ} 23^{\prime} 15^{\prime \prime} \mathrm{N} ; 02^{\circ} 07^{\prime} 05^{\prime \prime} \mathrm{E} ; 80$ m.a.s.l.) was situated at the western periphery of the city center in a small park. The road site (RS; $41^{\circ} 23^{\prime} 18^{\prime \prime} \mathrm{N} ; 02^{\circ} 09^{\prime} 00^{\prime \prime} \mathrm{E}$; $40 \mathrm{~m}$ a.s.l.) was located in a car park next to Urgell Street within the square-grid street network (Eixample) (Fig. 1). The road, which cuts the city from southeast to northwest, is a street canyon composed by a two-way cycling path and a one-way four-lane vehicle road. Vehicle intensity for the month of measurements was about 17000 vehicles per day. The two monitoring sites are located within $3 \mathrm{~km}$ from each other.

The meteorological data were measured in the sampling sites by means of automatic weather stations (Dall'Osto et al., 2013b). Air mass back trajectories were calculated daily during the sampling campaign. Four main air mass scenarios were identified during the SAPUSS field study (Dall'Osto et al., 2013b): Atlantic advection (2 periods; 7 days), North African - west ( 2 periods; 3 days), North African - east (1 period; 3 days), and Regional ( 2 periods; 8 days).

\subsection{Organic compounds analyzed}

The applied extraction method and instrumental analysis offers a selective sight on the total mass of the ambient air $\mathrm{PM}_{1}$. The usage of organic solvent mixture allows the extraction of a wide range of organic compounds with different polarities. Moreover, the instrumental analysis allows the detection of semi-volatile organics. During the years many of these compounds have been detected in emissions and ambient air samples, and therefore certain organic compounds can be used as tracers for sources and atmospheric processes. Table 1 shows the 36 organic compounds that were analyzed in the present study. They were selected based on their representativeness

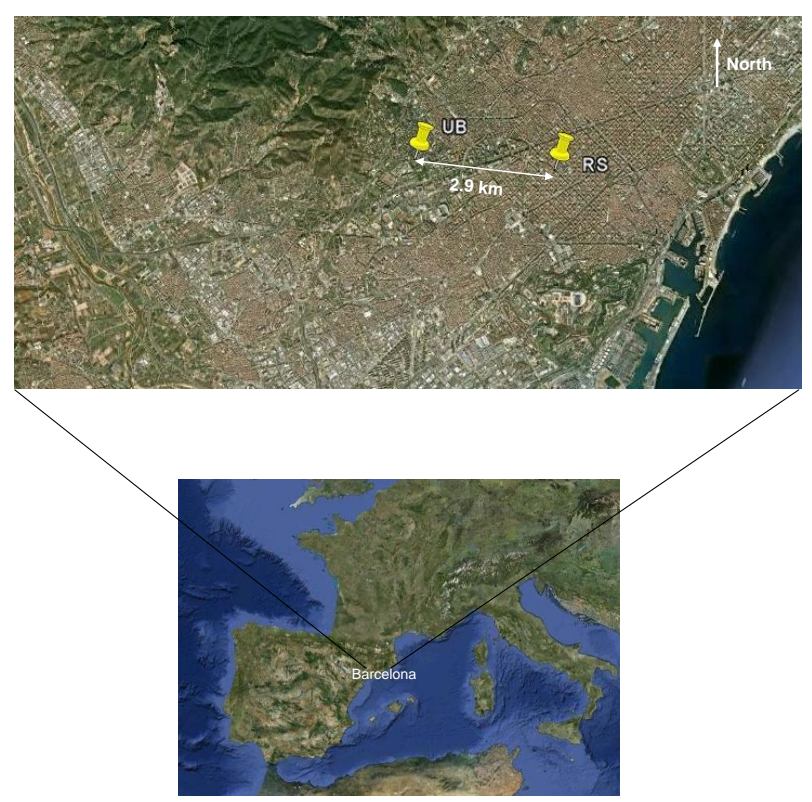

Fig. 1. Location of the sampling sites in Barcelona (source: Google Earth).

of primary organic aerosol emission sources and secondary organic aerosol formation. Briefly:

1. Polycyclic aromatic hydrocarbons (PAH, 12 in total). They are toxic components of fossil fuels and primary products of incomplete combustion of fossil fuels and biomass (Rogge et al., 1993; Schauer et al., 2007).

2. Hopanes $(17(\mathrm{H}) \alpha-21(\mathrm{H}) \beta$-29-norhopane and $17(\mathrm{H}) \alpha$ $21(\mathrm{H}) \beta$-hopane). They are molecular markers for mineral oils, and their presence can be related to unburned lubricating oil residues from primary vehicles emissions (Rogge et al., 1993; Schauer et al., 2007).

3. Nicotine. This alkaloid is present in high concentrations in environmental tobacco smoke. Although it is mainly present in the gas phase due to its relatively high volatility, it can be detected at trace levels on PM filter samples (Rogge et al., 1994; Bi et al., 2005).

4. Levoglucosan, galactosan and mannosan. They are monosaccharide anhydrides generated by thermal alteration of cellulose and hemi-cellulose. They are emitted in large quantities during biomass burning ( $\mathrm{Si}$ moneit et al., 2002; Fine et al., 2004).

5. Dicarboxylic acids (DCA), hydroxy-DCA and aromatic-DCA (11 in total, Table 1). They can be emitted from various primary sources (mobile emission, meat cooking, etc.) although atmospheric photo-chemical formation is probably the main source (Jang et al., 1997; Kerminen et al., 2000; Heald et al., 2010; Sheesley et al., 2010; Paulot et al., 2011). 
Table 1. Summary of the concentrations $\left(\mathrm{ng} \mathrm{m}^{-3}\right)$ of analyzed organic tracer compounds. The results indicated in bold showed significant $(t$ test, $p<0.05$ ) differences between sites, day and night, or between weekday (WD) and weekends/holidays (WE).

\begin{tabular}{|c|c|c|c|c|c|c|c|c|c|c|c|}
\hline & & \multicolumn{2}{|c|}{ UB } & \multicolumn{2}{|c|}{ RS } & \multicolumn{2}{|c|}{ UB vs. RS } & \multicolumn{2}{|c|}{ ratio day / night } & \multicolumn{2}{|c|}{ ratio $\mathrm{WD} / \mathrm{WE}$} \\
\hline & & mean sd & $(\min -\max )$ & mean sd & $(\min -\max )$ & ratio & $r^{2}$ & UB & RS & UB & RS \\
\hline \multirow{12}{*}{ 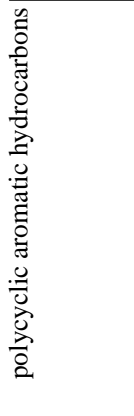 } & phenanthrene & $0.05 \pm 0.02$ & $(0.01-0.12)$ & $0.09 \pm 0.03$ & $(0.04-0.17)$ & 0.6 & 0.5 & 0.8 & 0.9 & 1.6 & 1.4 \\
\hline & anthracene & $0.01 \pm 0.00$ & $(0.00-0.02)$ & $0.02 \pm 0.01$ & $(0.01-0.04)$ & 0.5 & 0.4 & 1.0 & 1.1 & 1.5 & 1.6 \\
\hline & fluoranthene & $0.06 \pm 0.03$ & $(0.02-0.14)$ & $0.13 \pm 0.04$ & $(0.06-0.21)$ & 0.5 & 0.4 & 0.8 & 0.9 & 1.7 & 1.4 \\
\hline & pyrene & $0.08 \pm 0.05$ & $(0.02-0.22)$ & $0.20 \pm 0.07$ & $(0.10-0.38)$ & 0.4 & 0.4 & 0.8 & 0.9 & 1.9 & 1.5 \\
\hline & benz[a]anthracene & $0.05 \pm 0.03$ & $(0.02-0.12)$ & $0.13 \pm 0.05$ & $(0.04-0.24)$ & 0.4 & 0.4 & 0.9 & 1.3 & 1.7 & 1.8 \\
\hline & chrysene & $0.07 \pm 0.03$ & $(0.02-0.14)$ & $0.16 \pm 0.07$ & $(0.05-0.31)$ & 0.4 & 0.5 & 0.9 & 1.2 & 1.6 & 1.7 \\
\hline & benzofluoranthenes & $0.13 \pm 0.07$ & $(0.03-0.37)$ & $0.17 \pm 0.09$ & $(0.03-0.48)$ & 0.7 & 0.3 & 1.0 & 1.2 & 1.3 & 1.5 \\
\hline & benzo[e]pyrene & $0.15 \pm 0.08$ & $(0.05-0.37)$ & $0.33 \pm 0.16$ & $(0.07-0.73)$ & 0.4 & 0.5 & 0.9 & 1.3 & 1.7 & 1.9 \\
\hline & benzo[a]pyrene & $0.06 \pm 0.04$ & $(0.01-0.20)$ & $0.18 \pm 0.09$ & $(0.03-0.40)$ & 0.4 & 0.4 & 0.9 & 1.3 & 1.6 & 2.1 \\
\hline & indeno[123cd]pyrene & $0.04 \pm 0.03$ & $(0.01-0.12)$ & $0.11 \pm 0.06$ & $(0.02-0.27)$ & 0.4 & 0.2 & 0.9 & 1.2 & 1.0 & 1.5 \\
\hline & benzo[ghi]perylene & $0.12 \pm 0.05$ & $(0.04-0.26)$ & $0.30 \pm 0.13$ & $(0.07-0.56)$ & 0.4 & 0.4 & 0.9 & 1.4 & 1.4 & 1.9 \\
\hline & coronene & $0.04 \pm 0.02$ & $(0.01-0.08)$ & $0.09 \pm 0.03$ & $(0.03-0.17)$ & 0.5 & 0.2 & 1.0 & 1.4 & 1.2 & 1.5 \\
\hline \multirow[t]{2}{*}{ hopanes } & $17 \mathrm{a}(\mathrm{H}) 21 \beta(\mathrm{H})-29$-norhopane & $0.52 \pm 0.22$ & $(0.20-1.11)$ & $0.73 \pm 0.37$ & $(0.20-1.70)$ & 0.7 & 0.5 & 1.1 & 1.1 & 1.5 & 2.0 \\
\hline & $17 \mathrm{a}(\mathrm{H}) 21 \beta(\mathrm{H})$-hopane & $0.46 \pm 0.22$ & $(0.19-1.16)$ & $0.79 \pm 0.41$ & $(0.20-1.88)$ & 0.6 & 0.5 & 1.0 & 1.1 & 1.6 & 2.0 \\
\hline alkaloid & nicotine & $7.0 \pm 5.6$ & $(0.5-20.0)$ & $58.1 \pm 39.8$ & $(9.2-164)$ & 0.1 & 0.4 & 1.3 & 1.5 & 1.8 & 2.5 \\
\hline \multirow{3}{*}{$\begin{array}{l}\text { anhydro- } \\
\text { sugars }\end{array}$} & levoglucosan & $9.4 \pm 9.4$ & $(1.7-40.0)$ & $5.3 \pm 5.8$ & $(0.6-30.5)$ & 1.8 & 0.8 & 0.9 & 0.9 & 0.7 & 0.8 \\
\hline & galactosan & $1.3 \pm 1.6$ & $(0.2-7.1)$ & $0.7 \pm 0.9$ & $(0.1-4.4)$ & 1.8 & 0.8 & 0.9 & 0.9 & 0.6 & 0.9 \\
\hline & mannosan & $1.2 \pm 1.4$ & $(0.2-5.6)$ & $0.6 \pm 0.7$ & $(0.1-3.8)$ & 1.9 & 0.8 & 0.8 & 0.9 & 0.6 & 0.7 \\
\hline \multirow{18}{*}{ 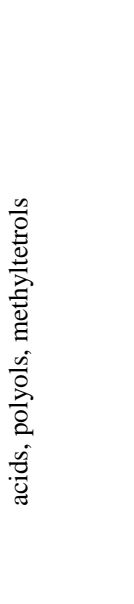 } & malonic acid $\mathrm{C}_{3}$ & $1.5 \pm 1.5$ & $(0.3-8.1)$ & $1.6 \pm 1.0$ & $(0.4-4.9)$ & 1.0 & 0.5 & 1.1 & 1.3 & 0.9 & 1.2 \\
\hline & succinic acid $\mathrm{C}_{4}$ & $7.3 \pm 4.8$ & $(3.1-24.7)$ & $6.2 \pm 3.0$ & $(2.5-14.8)$ & 1.2 & 0.3 & 1.1 & 1.0 & 0.9 & 0.9 \\
\hline & glutaric acid $\mathrm{C}_{5}$ & $2.0 \pm 1.3$ & $(0.6-7.5)$ & $1.5 \pm 0.7$ & $(0.6-3.2)$ & 1.3 & 0.3 & 1.3 & 1.2 & 1.0 & 1.0 \\
\hline & pimelic acid $\mathrm{C}_{7}$ & $0.6 \pm 0.3$ & $(0.2-2.1)$ & $1.3 \pm 0.6$ & $(0.6-3.7)$ & 0.5 & 0.5 & 1.3 & 1.6 & 0.9 & 1.0 \\
\hline & suberic acid $\mathrm{C}_{8}$ & $0.9 \pm 0.5$ & $(0.4-3.0)$ & $1.7 \pm 0.7$ & $(0.7-3.9)$ & 0.5 & 0.2 & 1.2 & 1.5 & 1.0 & 1.0 \\
\hline & azelaic acid $\mathrm{C}_{9}$ & $2.9 \pm 1.3$ & $(1.0-7.3)$ & $6.1 \pm 2.6$ & $(2.4-13.0)$ & 0.5 & 0.2 & 1.2 & 1.7 & 1.0 & 1.2 \\
\hline & glyceric acid & $3.2 \pm 2.9$ & $(0.7-15.2)$ & $3.4 \pm 2.0$ & $(1.1-9.8)$ & 0.9 & 0.5 & 1.0 & 1.1 & 0.9 & 1.1 \\
\hline & malic acid & $14.2 \pm 14.3$ & $(1.2-72.7)$ & $9.9 \pm 8.5$ & $(1.2-33.6)$ & 1.4 & 0.7 & 1.2 & 1.0 & 1.0 & 0.9 \\
\hline & tartaric acid & $2.1 \pm 2.8$ & $(0.0-12.2)$ & $1.8 \pm 1.7$ & $(0.1-7.0)$ & 1.2 & 0.6 & 1.5 & 1.2 & 0.9 & 0.9 \\
\hline & tricarballytic acid & $3.9 \pm 3.3$ & $(0.3-15.3)$ & $3.0 \pm 2.4$ & $(0.4-11.6)$ & 1.3 & 0.6 & 1.2 & 1.2 & 1.1 & 0.9 \\
\hline & phthalic acid & $3.9 \pm 2.4$ & $(0.9-11.4)$ & $3.6 \pm 1.6$ & $(1.3-9.3)$ & 1.1 & 0.7 & 1.4 & 1.2 & 1.1 & 1.1 \\
\hline & 3-hydroxyglutaric acid & $4.5 \pm 3.5$ & $(0.5-20.2)$ & $3.1 \pm 2.1$ & $(0.8-8.6)$ & 1.5 & 0.7 & 1.1 & 1.0 & 1.0 & 1.1 \\
\hline & MBTCA & $5.5 \pm 4.5$ & $(1.0-23.5)$ & $4.1 \pm 2.4$ & $(0.7-10.3)$ & 1.4 & 0.6 & 1.3 & 1.3 & 1.2 & 1.2 \\
\hline & cis-pinonic acid & $15.4 \pm 8.4$ & $(3.6-49.7)$ & $8.0 \pm 2.9$ & $(3.1-18.4)$ & 1.9 & 0.6 & 1.0 & 1.1 & 1.0 & 1.0 \\
\hline & $\mathrm{C}_{5}$-alkene triols & $1.0 \pm 0.7$ & $(0.1-3.0)$ & $0.7 \pm 0.5$ & $(0.1-2.2)$ & 1.4 & 0.7 & 1.1 & 1.0 & 1.2 & 1.4 \\
\hline & 2-methylglyceric acid & $2.1 \pm 1.3$ & $(0.4-6.4)$ & $1.9 \pm 1.1$ & $(0.6-4.5)$ & 1.1 & 0.5 & 1.2 & 1.1 & 1.1 & 1.3 \\
\hline & 2-methylthreitol & $2.8 \pm 1.6$ & $(0.6-7.8)$ & $1.4 \pm 0.9$ & $(0.1-3.8)$ & 1.9 & 0.6 & 1.1 & 1.0 & 1.2 & 1.1 \\
\hline & 2-methylerythritol & $6.5 \pm 4.1$ & $(1.7-20.7)$ & $3.5 \pm 2.4$ & $(0.6-9.5)$ & 1.9 & 0.6 & 1.1 & 1.0 & 1.2 & 1.2 \\
\hline
\end{tabular}

6. Cis-pinonic acid, 3-hydroxyglutaric acid and 3methyl-1,2,3-butanetricarboxylic acid (MBTCA). They have been identified in aerosols and related to the photo-chemical oxidation of biogenic volatile compounds such as $\alpha$-pinene (Claeys et al., 2007; Szmigielski et al., 2007). 3-MBTCA is formed by OHinitiated oxidation of cis-pinonic acid (Szmigielski et al., 2007) and was first detected in aerosol samples from Amazonia and Belgium (Kubatova et al., 2000). It is worth noting that the most abundant monoterpene in the study area presented in this manuscript is $\alpha$-pinene (Seco et al., 2011).

7. 2-methylglyceric acid and polyols, such as $\mathrm{C}_{5}$ alkene triols and 2-methyltetrols. They have been related to isoprene oxidation (Claeys et al., 2004; Hallquist et al., 2009), a major volatile organic compound emitted from land vegetation.

\subsection{Analytical procedure}

Digitel-DH80 HiVol samplers were used to collect $103 \mathrm{PM}_{1}$ filters (Pall Life Sciences; TISSUEQUARTZ 2500QAT-UP), each encompassing $12 \mathrm{~h}$ sampling hours, between 09:00 and 21:00 (UTC), at a sampling rate of $30 \mathrm{~m}^{3} \mathrm{~h}^{-1}$. More information can be found elsewhere (Dall'Osto et al., 2013b). All filters were preheated at $450{ }^{\circ} \mathrm{C}$ overnight before sampling. A $1 / 8$ section of each filter was preserved for analysis of organic compounds. This section was ultrasonically extracted with $(2: 1, v / v)$ dichloromethane : methanol $(3 \times 5 \mathrm{~mL}$; Merck, Germany) for $15 \mathrm{~min}$. Before extraction $25 \mu \mathrm{L}$ of the surrogate standards levoglucosan- $\mathrm{d}_{7}, \mathrm{n}-\mathrm{C}_{24} \mathrm{~d}_{50}$ 
(Cambridge Isotopic Laboratories, UK), succinic acid- $\mathrm{d}_{4}$ (Sigma Aldrich), anthracene- $\mathrm{d}_{10}$, benz[a]anthrancene- $\mathrm{d}_{12}$, benzo[k]fluoranthene- $\mathrm{d}_{12}$ and benzo[ghi]perylene- $\mathrm{d}_{12}$ (Dr. Ehrenstorfer) were added. The extracts were filtered over $0.45 \mu \mathrm{m}$ teflon membrane filters (Whatman) in order to remove insoluble particles. Then, they were concentrated to $1 \mathrm{~mL}$ under a gentle $\mathrm{N}_{2}$-gas stream.

Anhydro saccharides, acids, polyols and nicotine were analyzed following a procedure that was similar to others described previously (El Haddad et al., 2011; Medeiros and Medeiros, 2007; van Drooge et al., 2012a). Briefly, an aliquot of the extract $(25 \mu \mathrm{L})$ was evaporated under a gentle $\mathrm{N}_{2}$ stream until dryness. Then, $25 \mu \mathrm{L}$ of bis(trimethylsilyl)trifluoroacetamide (BSFTA)+trimethylchlorosilane (99:1) (Supelco) and $10 \mu \mathrm{L}$ of pyridine (Merck) were added for derivatization of the saccharides, acids and polyols to their trimethylsilyl esters at $70^{\circ} \mathrm{C}$ during $1 \mathrm{~h}$. Before injection into a gas chromatograph coupled to a mass spectrometer (GC-MS), $25 \mu \mathrm{L}$ of the internal standard, pyrene- $\mathrm{d}_{10}$, were added to the vial.

For the analysis of polycyclic aromatic hydrocarbons and hopanes, the remaining extract was evaporated to almost dryness under a gentle $\mathrm{N}_{2}$-gas stream and re-dissolved in $0.5 \mathrm{~mL}$ hexane+dichloromethane $(9: 1 v / v)$ (Merck, Germany). Then, it was cleaned up by adsorption column chromatography on $1 \mathrm{~g}$ of aluminum oxide (Merck, Germany) that was activated overnight at $120^{\circ} \mathrm{C}$. The analytes were eluded with $4 \mathrm{~mL}$ of $(9: 1 v / v)$ hexane:dichloromethane and $4 \mathrm{~mL}$ of $(1: 2 v / v)$ hexane:dichloromethane, respectively (Merck, Germany). The collected fraction was concentrated under a gentle $\mathrm{N}_{2}$-gas stream to $50 \mu \mathrm{L}$, and the internal standard, pyrene- $\mathrm{d}_{10}$, was added before injection into GC.

Sample extracts were injected into a Thermo GC/MS (Thermo Trace GC Ultra - DSQ II) equipped with a $60 \mathrm{~m}$ fused capillary column (HP-5MS $0.25 \mathrm{~mm} \times 25 \mu \mathrm{m}$ film thickness). The oven temperature program started at $60^{\circ} \mathrm{C}$ held for $1 \mathrm{~min}$, and then it was heated to $120^{\circ} \mathrm{C}$ at $12^{\circ} \mathrm{C} \mathrm{min}^{-1}$ and to $310^{\circ} \mathrm{C}$ at $4{ }^{\circ} \mathrm{C} \mathrm{min}^{-1}$ where it was held for $10 \mathrm{~min}$. The injector, ion source, quadrupole and transfer line temperatures were $280^{\circ} \mathrm{C}, 200^{\circ} \mathrm{C}, 150^{\circ} \mathrm{C}$ and $280^{\circ} \mathrm{C}$, respectively. Helium was used as a carrier gas at $0.9 \mathrm{~mL} \mathrm{~s}^{-1}$. The MS selective detector was operated in fullscan $(\mathrm{m} / z 50$ $650)$ and electron impact $(70 \mathrm{eV})$ ionization modes.

Besides comparison of retention times, levoglucosan and mannosan were identified with ion $m / z$ 204, galactosan with ion $m / z 217$ and nicotine with ion $m / z$ 84. Acids, polyols and 2-methyltetrols were identified with the following ions: malonic acid $(\mathrm{m} / \mathrm{z} 233)$, succinic acid $(\mathrm{m} / \mathrm{z} 247)$, glutaric acid $(m / z 261)$, pimelic acid $(m / z 289)$, suberic acid $(m / z 303)$, azelaic acid $(m / z 317)$, glyceric acid $(m / z$ 292), malic acid $(m / z$ 233), tartaric acid $(m / z$ 292), phthalic acid $(m / z 295)$, tricarballytic acid $(m / z$ 377), cispinonic acid $(\mathrm{m} / \mathrm{z}$ 171), 3-hydroxyglutaric acid $(\mathrm{m} / \mathrm{z}$ 349), 3methyl-1,2,3-butanetricarboxylic acid (MBTCA) $(m / z 405)$, 2-methylglyceric acid $(m / z 219), \mathrm{C}_{5}$-alkene triols $(m / z 231)$, 2-methylthreitol and 2-methylerythritol $(m / z$ 219). Quantification was performed with the external standard calibration curves. All concentrations were corrected by the recoveries of the surrogate standard succinic acid $(m / z 251)$ and levoglucosan- $\mathrm{d}_{7}(m / z$ 206). No standards were available for 3-hydroxyglutaric acid, MBTCA, 2-methylglyceric acid, $\mathrm{C}_{5}$ alkene triols, 2-methylthreitol and 2-methylerythritol. Their chromatographic peaks were identified by comparison of their mass spectra to literature and library data (Claeys et al., 2007; Kourtchev et al., 2005; Clements and Seinfeld, 2007), and they were quantified with the calibration curve of succinic acid. Application of the calibration curves of other standards leads to lower concentrations with a maximum variation of factor of 3 . Therefore, caution should be taken when comparing these results with those from other studies.

PAH were identified by retention time comparison of the peaks with the following ions in SIM mode: phenanthrene $(\mathrm{m} / \mathrm{z} 178)$, anthracene $(\mathrm{m} / \mathrm{z} 178)$, fluoranthene $(\mathrm{m} / \mathrm{z}$ 202), pyrene $(m / z 202)$, benz[a]anthracene $(m / z 228)$, chrysene+triphenylene $(\mathrm{m} / \mathrm{z} 228)$, benzo[b]fluoranthene $(\mathrm{m} / \mathrm{z} 252)$, benzo[k]fluoranthene $(\mathrm{m} / \mathrm{z} 252)$, benzo[e]pyrene $(m / z \quad 252)$, benzo[a]pyrene $(m / z \quad 252)$, indeno[1,2,3cd]pyrene $(m / z 276)$, benzo[ghi]perylene $(m / z$ 276) and coronene $(m / z$ 300). 17(H) $\alpha-21(\mathrm{H}) \beta$-29-Norhopane and $17(\mathrm{H}) \alpha-21(\mathrm{H}) \beta$-hopane were identified in the $\mathrm{m} / z 191$ mass fragmentogram and the corresponding retention times. Quantification was also performed by the external standard method, and the calculated concentrations were corrected for the recoveries of the abovementioned surrogates: anthracene- $\mathrm{d}_{10}(\mathrm{~m} / \mathrm{z} \quad 188)$, benz[a]anthrancene$\mathrm{d}_{12}(\mathrm{~m} / \mathrm{z}, 240)$, benzo[k]fluoranthene- $\mathrm{d}_{12}(\mathrm{~m} / \mathrm{z} 264)$ and benzo[ghi]perylene-D $\mathrm{D}_{12}(\mathrm{~m} / \mathrm{z} 288)$.

In all cases the recoveries of the surrogate standards were higher than $70 \%$. Field blank levels were between $1 \%$ and $30 \%$ of the sample levels. All concentrations were corrected for blank levels. Limits of quantification (LOQ) were calculated by dividing the lowest measured levels in the standard calibration curves by the volumes of the analyzed sample fraction. These were $0.1 \mathrm{ng} \mathrm{m}^{-3}$ for the anhydrosaccharides, $0.06 \mathrm{ng} \mathrm{m}^{-3}$ for the acids and $0.005 \mathrm{ng} \mathrm{m}^{-3}$ for PAHs and hopanes.

\subsection{Chemometrics}

MCR-ALS method has been successfully used in the analysis of environmental data sets, both in contamination studies of surface waters (Terrado et al, 2009) and in air source apportionment studies (Salau et al., 1997; Tauler et al., 2009). One of the main advantages of MCR-ALS is that it decomposes the data matrix by applying more natural constraints than PCA, such as non-negativity, and, therefore, interpretation of results is more straightforward.

MCR-ALS is based on a bilinear decomposition of the original data set. In matrix form, it is expressed as $\mathbf{D}(I \times J)$ 
$=\mathbf{U}(I \times N) \mathbf{V}^{T}(N \times J)+\mathbf{E}(I \times J)$, where $\mathbf{D}$ is the original data array, with $I$ rows (samples) and $J$ columns (compounds); $\mathbf{U}$ is the matrix of scores of dimensions $I \times N$, where $N$ is the reduced number of components; $\mathbf{V}^{T}$ is the matrix of loadings with dimensions $N \times J$; and $\mathbf{E}$ is the matrix of residuals not modeled by the $N$ components. The MCR-ALS method decomposes the data matrix using an alternating least squares algorithm under a set of constraints such as non-negativity, unimodality, closure, trilinearity or selectivity (Tauler et al., 1995; Tauler, 1995; Jaumot et al., 2005). The variance explained by the different components is overlapped and not orthogonal (non-overlapped) as in PCA (Jolliffe, 2002). Natural sources in the environment are rarely orthogonal; thus the MCR methods may have a physically sounder interpretation than orthogonal database decomposition methods.

For the multivariate data analysis, the experimental data were stored in $12 \mathrm{~h}$ periods between 22 September 2010 and 18 October 2010 at the two sites. This generated data matrices of 52 and 51 samples for UB and RS stations, and the number of compounds analyzed in each was 35 . Indeno[123cd]pyrene was finally excluded from the databases because $20 \%$ of the sample concentrations were below LOQ. The merged matrix $(52 \times 35$ for UB and $51 \times 35$ for RS $)$ allows a better comparison of potential source apportionment profiles than the individual matrices. The observed sources are representative of the two monitoring sites. The joint data set was imported into MATLAB 7.4 (The Mathworks, Natick, USA) for subsequent calculations using MATLAB PLS 5.8 Toolbox (Eigenvector Research Inc, Masson, WA, USA).

\section{Results}

\subsection{Chemical analysis of $\mathbf{P M}_{1}$ filter samples}

Means, standard deviations $( \pm 1 \sigma)$, maximum and minimum concentration values of the compounds analyzed are described in Table 1.

\subsubsection{PAH}

The total concentrations of the 12 PAHs analyzed were two times higher at the RS $\left(1.91 \mathrm{ng} \mathrm{m}^{-3}\right)$ than at the UB site $\left(0.89 \mathrm{ng} \mathrm{m}^{-3}\right)$, reflecting a stronger influence of residues from fossil fuel vehicles at the former site. This difference was similar to that observed for the concentrations of $\mathrm{NO}_{\mathrm{x}}$ ( 46 vs. $33 \mu \mathrm{g} \mathrm{m}^{-3}$ ) and elemental carbon (1.4 vs. $0.7 \mu \mathrm{g} \mathrm{m}^{-3}$ ) (Dall'Osto et al., 2013b). Despite these differences in concentrations, there was a significant, moderately positive correlation between the PAH concentrations at the two sites $\left(r^{2}=0.55, P<0.05\right)$. This can be interpreted to reflect the atmospheric conditions affecting the distributions of primary atmospheric pollutants in the urban area under study.

The average isomeric ratios fluoranthene vs. pyrene $(\mathrm{Fl} /(\mathrm{Fl}+\mathrm{Pyr})$, benz[a]anthracene vs. chrysene
$(\mathrm{BaA} /(\mathrm{BaA}+\mathrm{Chr})$, benzo[e]pyrene vs. benzo[a]pyrene $(\mathrm{BeP} /(\mathrm{BeP}+\mathrm{BaP})$, and indeno[123cd]pyrene vs. benzo[ghi]perylene $\quad(\mathrm{IP} /(\mathrm{IP}+\mathrm{BgP}) \quad-\quad 0.42 \pm 0.05$, $0.43 \pm 0.03, \quad 0.68 \pm 0.06$ and $0.26 \pm 0.09$, respectively - were very similar among all analyzed samples at both sites. These ratios are consistent with a dominance of fossil fuel combustion inputs from traffic related activities (Galarneau et al., 2008).

At the RS, the detected PAH of high molecular weight (PAH_high, $m / z>228$; see Table 1 ) showed higher concentrations during daytime than at nighttime $(1.3, P<0.05)$, whereas no difference was found for PAH of low molecular weight (PAH_low, $m / z>228$; see Table 1). By contrast, at the UB site no day/night difference was found for all the PAH detected. Several factors could be responsible for the day/night pattern of PAH concentrations at the RS site, including traffic intensity, vehicle fleet (e.g. diesel, gasoline) and meteorological conditions (e.g. temperature). Although the traffic intensity showed a marked day/night trend (ratio 2.4), the PAH concentrations did not correlate with such intensity. Such low correlation may be due to gas to particle partitioning of PAH compounds, which has a stronger influence on the more volatile PAH_low (Lohmann and Lammel, 2004).

The observed $\sum \mathrm{PAH}$ concentrations in Barcelona were in the range of the ones observed in other urban areas in the USA (Ning et al., 2007; Subramanian et al., 2006) and Europe (Křumal et al., 2013, and references therein), although wintertime concentrations in those site are generally higher, due to enhanced fuel combustion for domestic heating. The relative composition of the PAH compounds in the ambient air PM in Barcelona was found enriched with lower molecular weight PAH (PAH_low; phenanthrene until pyrene; $m / z<228$ ), whereas the $\mathrm{PM}_{1}$ in the uban areas in the USA were more enriched with higher molecular weight PAH (PAH_high; benz[anthracene until coronene; $m / z>228$ ). These differences between the urban locations could be due to the higher proportion of diesel engine vehicles over gasoline vehicle in Barcelona in comparison to the sites in the USA, where gasoline vehicles dominate (Rogge et al., 1993; Zielinska et al., 2004).

Finally, it is worth noting that the PAH concentrations were about a factor 1.5 higher during weekdays in comparison to weekends/holidays days at both sites (Table 1), and this factor was found to be similar to the one of vehicle intensities near the two monitoring sites (1.4; Dall Osto et al., 2013a).

\subsubsection{Hopanes}

Total hopanes concentrations were $0.75 \mathrm{ng} \mathrm{m}^{-3}$ and $0.50 \mathrm{ng} \mathrm{m}^{-3}$ at RS and at the UB sites, respectively (Table 1), reflecting - likewise for the PAH concentrations the strong influence of fossil fuel vehicle combustion at the former site. The observed $\sum$ hopane concentrations in BCN 
fit into the range of the concentrations observed in urban areas in the USA and Europe (Subramanian et al., 2006; Ning et al., 2007; Křumal et al., 2013). Although hopanes are susceptible to oxidation in the atmosphere (Robinson et al., 2006a; Lambe et al., 2009), the depletion is probably small due to the very short distance between the sampling site and emission source. Temporal trends of hopanes were also found to be moderately correlated between the two monitoring sites $\left(r^{2}=0.65, P<0.05\right)$. There were no differences between day and night periods, likewise for the PAH_low concentrations. The relationship between PAH_low and hopanes reflects the primary emissions of diesel vehicles (Rogge et al., 1993; Zielinska et al., 2004). Higher concentrations were observed during weekdays in comparison to weekends/holidays (factor 1.6 at UB and 2 at RS, respectively; Table 1).

\subsubsection{Nicotine}

This alkaloid was found in all filter samples. Much higher concentrations $\left(58 \mathrm{ng} \mathrm{m}^{-3}\right)$ were observed at the RS site than at UB $\left(7 \mathrm{ng} \mathrm{m}^{-3}\right)$. This eight-fold difference points to a very strong outdoor cigarette consumption near RS, which is situated next to a busy street and an exit of an underground metro station. The UB sampling station is situated in a local park and is away from streets and pedestrians. It is worth noting that Spain ranks among the countries of highest cigarette consumption in the European Union and in the world (WHO, 2010). High outdoor gas-phase nicotine concentrations were previously measured in Barcelona in summer 2010 between 0.5 and $1.5 \mu \mathrm{g} \mathrm{m}^{-3}$ (Sureda et al., 2012).

Nicotine concentrations showed a moderate correlation $\left(r^{2}=0.4, P<0.05\right)$ between the two monitoring sites, suggesting that the whole urban atmosphere of Barcelona was generally influenced by outdoor tobacco smoke. At RS nicotine concentrations had a day / night ratio of $1.5(P<0.05)$ at the RS, whereas a statistical difference was not found at the UB site. Significantly higher nicotine concentrations were detected during weekdays than on weekends/holidays (ratio of 1.8 and 2.5 at UB and RS, respectively, $P<0.05$; Table 1). This indicates that the nicotine concentrations are more affected by anthropogenic working activities during daytime of the weekdays rather than leisure ones occurring during weekends. This result is in line with other SAPUSS studies of single particle aerosol time-of-flight mass spectrometry showing that nicotine concentrations correlate with traffic activities and not with gastronomic ones (Dall'Osto et al., 2013b).

\subsubsection{Anhydro saccharides}

In this group of compounds, mannosan and galactosan showed low concentrations (about $2-4 \mathrm{ng} \mathrm{m}^{-3}$ ), and also the levoglucosan concentrations were relatively low ( 9 and $5 \mathrm{ng} \mathrm{m}^{-3}$ at UB and RS, respectively; Table 1). These lev- els are similar to previous studies in the same region during the summer season (van Drooge et al., 2012b) and in European background sites with low influence of biomass burning (Puxbaum et al., 2007). In contrast, higher levoglucosan concentrations were found at the UB site in former studies conducted during wintertime (35-60 $\mathrm{ng} \mathrm{m}^{-3}$, Reche et al., 2012; van Drooge et al., 2012a). In the present study, these high levels were only observed at both sites at the end of the sampling period (about $35 \mathrm{ng} \mathrm{m}^{-3}, 15-20$ October 2010). This increase was coincident with the legal permission of burning biomass waste in regional background fields from 15 October and onwards (DOGC 1995) as well as with a stagnant regional anticyclonic conditions (Dall'Osto et al., 2013b). The temporal concentration changes of the anhydro saccharides compounds at both sites were very similar $\left(r^{2}=0.88\right.$, $P<0.05)$.

However, the higher levels found at the UB site relative to the RS site (ratio $1.9 ; P<0.05$ ) are likely due to the higher exposure of the UB site from regional sources because the RS site is located within a network of streets that reduce natural ventilation. This difference between the two stations was more defined in the last period of the sampling when higher concentrations were detected.

\subsubsection{Dicarboxylic acids (DCA), hydroxy-DCA and aromatic-DCA}

Mean concentrations of individual DCA compounds were found ranging between 1 and $14 \mathrm{ng} \mathrm{m}^{-3}$ and between 1 and $10 \mathrm{ng} \mathrm{m}^{-3}$ at the UB and RS, respectively. The highest individual mean concentrations at both sites were observed for malic acid (14 $\mathrm{ng} \mathrm{m}^{-3}$ at $\mathrm{UB} ; 10 \mathrm{ng} \mathrm{m}^{-3}$ at RS) and succinic acid ( $7 \mathrm{ng} \mathrm{m}^{-3}$ at UB; $6 \mathrm{ng} \mathrm{m}^{-3}$ at RS). This range of concentrations is similar to those measured during wintertime at the UB site (Van Drooge et al., 2012a). The higher ratio of malic acid/succinic acid was previously observed in other sites influenced by anthropogenic emission sources (Yang et al., 2008a). Phthalic acid - a secondary organic tracer for fossil fuel combustion - showed similar mean concentrations at both sites $\left(4 \mathrm{ng} \mathrm{m}^{-3}\right.$, Table 1$)$. As regards the temporal trends of the DCA concentrations during SAPUSS, the majority of them were found similar between the two monitoring sites $\left(0.2<r^{2}<0.8, P<0.05\right.$; Table 1$)$.

Most DCA concentrations were found slightly higher at the UB site relative to the RS one (UB/RS about 1.2), with the exception of the $\mathrm{C}_{7}-\mathrm{C}_{9}$ dicarboxylic acids (pimelic, suberic and azelaic acids), which were found to possess a UB / RS ratio of 0.5 . Moreover, in contrast to any of the other analyzed compounds, $\mathrm{C}_{7}-\mathrm{C}_{9}$ dicarboxylic acids showed a clear daytime maximum in their concentrations, especially at the RS site (Table 1). Among the $\mathrm{C}_{7}-\mathrm{C}_{9}$ DCA analyzed, azelaic acid showed the highest concentrations $\left(3 \mathrm{ng} \mathrm{m}^{-3}\right.$ and $6 \mathrm{ng} \mathrm{m}^{-3}$ at UB and RS, respectively). The presence of azelaic acid in ambient air PM has been related to fast oxidation of unsaturated fatty acids, i.e. oleic acid, by ozone (Gogou et al., 
1994; Moise and Rudich, 2002). The oxidation of biogenic precursors can also be an important source of $\mathrm{C}_{7}-\mathrm{C}_{9}$ dicarboxylic acids (Kawamura and Gagosian, 1987; Stephanou and Stratigakis, 1993; Mochida et al., 2003; Zhang et al., 2010; Ho et al., 2011). Oleic acid in the urban atmosphere may have many sources, such as food cooking, traffic and biogenic sources, including the marine environment (Fang et al., 2002; Schauer et al., 2002; Robinson et al., 2006b). In the present study, oleic acid was identified in all samples (including field blank filters) at low concentrations $\left(<2 \mathrm{ng} \mathrm{m}^{-3}\right)$. The lack of substantial oleic acid concentrations in the samples may be due to the chemical instability of this unsaturated fatty acid and/or a fast oxidation to other compounds in the urban atmosphere. Further considerations on possible sources and atmospheric processes responsible for the elevated azelaic acid concentrations detected are given in Sect. 3.2, where an aerosol source apportionment is attempted.

\subsection{6 $\alpha$-pinene SOA tracers: cis-pinonic acid, 3-hydroxyglutaric acid and MBTCA}

Cis-pinonic acid, 3-hydroxyglutaric acid and MBTCA, the three biogenic SOA tracers for $\alpha$-pinene oxidation, were detected in all samples. Cis-pinonic acid was found in twotimes higher concentrations at the UB sites $\left(15 \mathrm{ng} \mathrm{m}^{-3}\right)$ than at the RS site $\left(8 \mathrm{ng} \mathrm{m}^{-3}\right)$. The other two tracer compounds (3-hydroxyglutaric acid and MBTCA) showed lower average concentrations $\left(3-5 \mathrm{ng} \mathrm{m}^{-3}\right.$ ) (Table 1 ) but still statistically higher at UB. All the observed SOA pinene tracer concentrations are similar to the ones measured by El Haddad et al. (2011) in a nearby French Mediterranean urban area. There was no substantial correlation between the temporal concentration trends of cis-pinonic acid and the other two tracer compounds $\left(r^{2}=0.1\right)$, whereas there was a very good correlation between 3-hydroxyglutaric acid and MBTCA in the two different monitoring sites $\left(r^{2}=0.65 ; 0.75, P<\right.$ 0.05). The same correlations between these three biogenic SOA tracers were recently discussed by Ding et al. (2011). Oxidation of $\alpha$-pinene - emitted mainly by coniferous trees - forms pinic acid and cis-pinonic acid. Previous studies proposed that cis-pinonic acid and pinic acid could further photo-degrade to MBTCA (Claeys et al., 2007; Szmigielski et al., 2007). Although MBTCA has other precursors apart from $\alpha$-pinene (Szmigielski et al., 2007), the significant correlations among MBTCA and 3-hydroxyglutaric acid suggest that $\alpha$-pinene is probably its major precursor.

The ratio of cis-pinonic acid to MBTCA (P/M) can be employed to estimate the aging of $\alpha$-pinene SOA (Ding et al., 2011). The $P / M$ ratios at the UB and at the RS were 4.0 and 2.8 , respectively, indicating that overall the $\alpha$-pinene SOA tracers were relatively fresh during our campaign. It is important to note that cis-pinonic acid was found to possess the highest ratio between the two sites $(\mathrm{UB} / \mathrm{RS}=1.9)$ of all the 36 detected organic compounds in this study, implying this fresh SOA oxidation product may be further oxidized in the more urban city center (RS site).

\subsubsection{Isoprene SOA tracers: $\mathrm{C}_{5}$-alkene triols, 2-methylglyceric acid, 2-methylthreitol and 2-methylerythritol}

It is generally considered that the main atmospheric source of isoprenoid VOCs is the direct emission from vegetation (Guenter et al., 1995). However, tailpipe sources may also contribute a non-negligible amount of isoprene in urban areas (Borbon et al., 2001; Park et al., 2011). Indeed, previous studies in the metropolitan region of Barcelona described the human-related sources of isoprene (Seco et al., 2013). However, whilst the predominately anthropogenic origin is mainly seen in winter months, during the summer ones (including September and October, this study) a mainly biogenic origin is apportioned (Filella and Penuelas, 2006).

During SAPUSS, all the isoprene-related markers' concentrations were found higher at the UB site than the more anthropogenically influenced RS site (Table 1). Whilst it is not possible to uniquely attribute isoprene markers only to biogenic sources, previous urban air quality studies suggest that the majority of isoprene SOA should be of biogenic origin. For example, Langford et al. (2010) concluded that as much as $80 \%$ of isoprene in London has biogenic sources. Schneidemesser et al. (2011) concluded that isoprene does not have a very important role in atmospheric chemistry in London or Paris. However, given the unknown anthropogenic contribution, we leave this SOA isoprene aerosol source without a clear biogenic labeling.

During this study, $\mathrm{C}_{5}$-alkene triols concentrations (about $1 \mathrm{ng} \mathrm{m}^{-3}$ ) were slightly lower than those reported in other European sites (Kourtchev et al., 2005) and much lower than the levels of $300 \mathrm{ng} \mathrm{m}^{-3}$ in sites located in the southeastern USA (Lin et al., 2012). The 2-methylglyceric acid (2MGA) concentrations were in the same range as those observed in Marseille (about $2 \mathrm{ng} \mathrm{m}^{-3}$; El Haddad et al., 2011), whereas the levels of 2-methyltetrols (2-MT) were higher in the present study (about $2 \mathrm{ng} \mathrm{m}^{-3}$ ). 2-methylerythritol concentrations were 2.5 times higher than 2-methylthreitol concentrations. They were highly correlated within each other at both sites $\left(r^{2}=0.9 ; P<0.05\right)$, as previously observed in other studies (Edney et al., 2005; Ion et al., 2005; El Haddad et al., 2011). Overall there were good correlations between $\mathrm{C}_{5}$-alkene triols and $\sum 2$-methyltetrols $\left(r^{2}=0.8\right.$; $P<0.05)$, as well as between 2-MGA and $\mathrm{C}_{5}$-alkene triols, and $\sum 2$-methyltetrols $\left(r^{2}=0.6\right.$ and 0.7 , respectively; $P<$ 0.05 ). Overall, there was no day/night or weekdays/weekend significant difference at both monitoring sites for all the SOA isoprene markers. The concentrations of 2-MGA at UB were not significantly different than those observed at RS, whereas the 2-MT concentrations were about 2 times higher at UB.

Although both 2-MT and 2-MGA originate from the photo-oxidation of isoprene, NOx concentrations and aerosol 
acidity (Surratt et al., 2010) may affect their formation processes and consequently their relative abundances. Moreover, relative abundances of these organic compounds can evolve as they can undergo further photo-chemical processing or heterogeneous reactions upon their formation (Robinson et al., 2007). 2-MT are formed by photo-oxidation of isoprene under NO-limited conditions (Lin et al., 2012), while it is known that 2-MGA can also be formed by the further oxidation of volatile methacryloylperoxynitrate (MPAN), a major second-generation product of isoprene oxidation under initially high-NO conditions (Surratt et al., 2010). Recent work by Lin et al. (2013) found that 2-MGA is directly formed from methacrylic acid epoxide (MAE), which is a gas-phase oxidation product of MPAN. In summary, it is likely that the different traffic conditions encountered at the two monitoring sites, with higher NO at RS than UB, can impact the concentrations of 2-MGA and 2-MT.

\subsection{Multivariate data analysis}

Principal component analysis (PCA) was applied on a matrix of scaled concentrations to explore the amount of variance that could be explained by a reduced number of components and to identify the most determinant associations amongst the organic tracer compounds analyzed in this study. A sixcomponent solution was selected from the analysis involving a $96.5 \%$ of explained variance. Addition of a seventh component ( $97.2 \%$ of explained variance) did not show any further relevant environmental information.

Following the optimal number of components obtained by PCA, MCR-ALS was applied to the scaled column-wise data matrix (i.e. without mean-centering) and non-negativity constraints, resulting in six components which accounted for $96.2 \%$ of the total data variance.

Although many compounds were distributed between different MCR-ALS components for many of the chemical compounds, an insight of the contributions of the different OA sources can be seen in Fig. 2. The average organic carbon concentrations (OC, determined separately by the Sunset EC/OC instrument; Dall'Osto et al., 2013b) were found to be $3.5 \mu \mathrm{g} \mathrm{m}^{-3}$ at the RS and $2.1 \mu \mathrm{g} \mathrm{m}^{-3}$ at the UB site (Dall Osto et al., 2013b). There was a very good correlation between the total OC concentrations of $\mathrm{PM}_{1}$ and $\sum$ scores of component for each sampled day $\left(r^{2}=0.9, P<0.05\right)$, although between 2 and $6 \%$ of the total OC mass was chromatographically resolved. The excellent correlation indicates that the selected organic components described in this study can be representative for the contributions to the organic fraction sampled during the SAPUSS project. The percentages of OA contribution of each of the six components obtained were calculated from the relative contribution of the individual MCRALS resolved component with respect to the $\sum$ score of the six components. The mass contribution of OC per volume for each component (Fig. 2) was calculated by multiplying the relative contributions with the $\mathrm{OC}$ concentrations from
Dall'Osto et al. (2013b). The following sections discuss the unique features of the six OA sources identified, as well as the temporal trend of the scores. The percentages presented in brackets after the molecular markers represent the proportion of such marker among all six MCR-ALS profiles, and not the percentage of such marker among the total signal of the individual MCR-ALS profile.

\subsubsection{Urban Primary Organic Aerosol (POA Urban)}

This component is defined by strong contributions from PAH (43\%), hopanes (43\%) and nicotine $(79 \%)$ and accounts for $32 \%$ of the explained variance. The relatively larger contribution to the component of LMW PAH in combination with the hopanes points to diesel vehicles as an important emission source. Among the six components this is the one showing the best correlation with traffic intensity $\left(r^{2}=0.5\right)$, pointing to traffic as a major contributor to this component. This statement is further supported by the good correlation between this component and other traffic indicators, such as $\mathrm{NO}_{\mathrm{x}}\left(r^{2}=0.8\right), \mathrm{EC}_{P M 1}\left(r^{2}=0.7\right)$ and preliminary AMSPMF data on the hydrocarbon-like organic carbon (HOA; $\left.r^{2}=0.8\right)$ that were analyzed for the sampling sites.

The temporal changes of this source between the two sites were correlated $\left(r^{2}=0.5, P<0.05\right)$. POA Urban accounted for 0.35 and $1.5 \mu \mathrm{g} \mathrm{m}^{-3} \mathrm{OC}$ at UB (18\% of total OC) and RS (43\% of OC), respectively. This observation is consistent with a previous study (Mohr et al., 2012) in which $16 \%$ of the OA was attributed to primary organic aerosol at UB. In the urban area of Marseille along the Mediterranean coast a similar concentration of about $0.9 \mu \mathrm{g} \mathrm{OC} \mathrm{m}^{-3}(17 \%)$ was attributed to primary urban emissions (El Hadded et al., 2011) based on organic tracer analysis, while the primary emissions in Paris ranged between 0.2 and $0.5 \mu \mathrm{g} \mathrm{OC} \mathrm{m}{ }^{-3}$, depending on the used method.

POA Urban was higher during weekdays, especially on Wednesday and Thursday, whilst the lowest values were recorded during weekends and holidays (Fig. 2). There was no clear day-night fluctuation for this component, which is in accordance with the absence of such fluctuation in the LMW PAH and hopanes. The scores of this component are nearly equally divided among the four main air mass scenarios (Fig. 3), suggesting that it is less dependent on regional air mass transport and that local emissions are mainly responsible for the presence of such primary atmospheric pollutants in the urban area.

\subsubsection{Primary regional biomass burning organic aerosol (BBOA Regional)}

This component is essentially formed by levoglucosan $(68 \%)$, mannosan $(75 \%)$ and galactosan $(79 \%)$, several markers of primary biomass burning. The component also contains an important part of glyceric acid (45\%), which could be emitted after biomass burning or formed during 


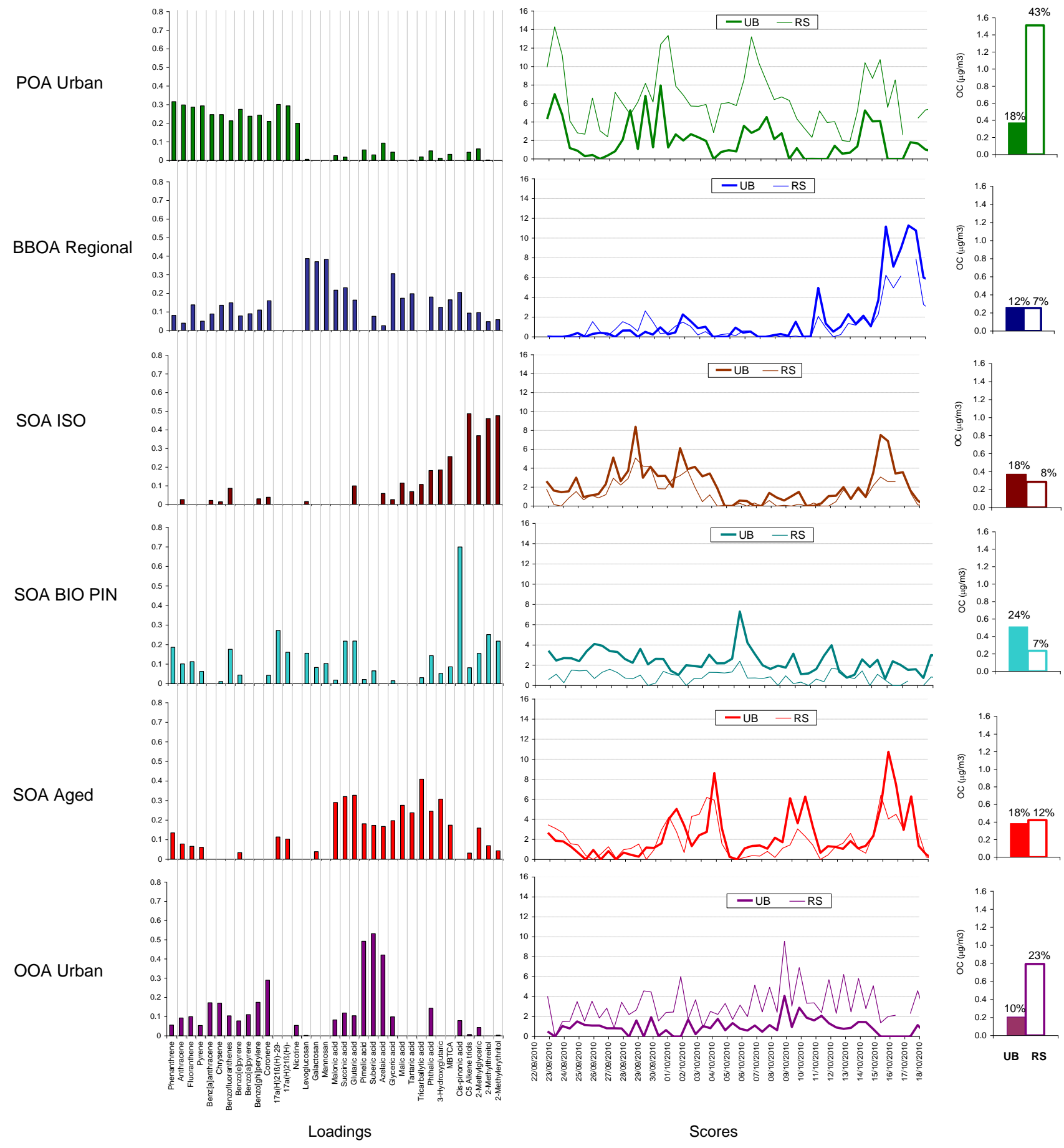

Fig. 2. MCR-ALS resolved profiles applying non-negativity constraints. Column on the left shows the loading organic compound composition of the six selected components. Column in the middle shows the temporal trend of the score values of the six components. Column on the right shows the relative contribution of the scores $(\%)$ as well as the estimated mass contribution of organic carbon to volume $\left(\mu \mathrm{g} \mathrm{OC}^{-3}\right)$.

atmospheric transport. Moderate contributions (about $20 \%$ of the total signal) from other DCAs and PAH are also observed (Fig. 2).
This component accounted for $15 \%$ of the total variance and its values in the two sites were strongly correlated $\left(r^{2}=\right.$ $0.85)$. The highest score values in both sites were observed in the last sampling period of the SAPPUSS campaign (15- 

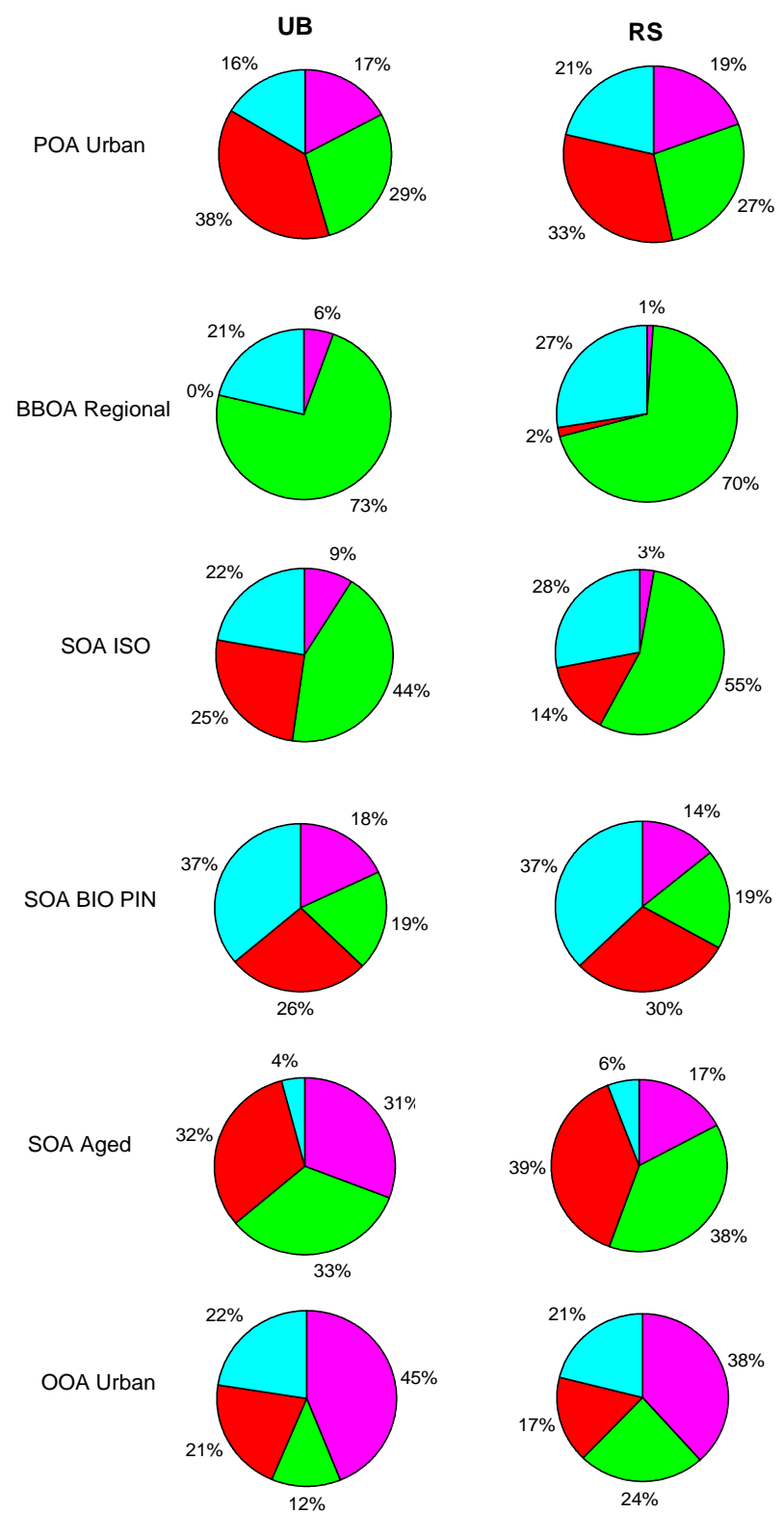

口NAF_E $\square R E G . \quad \square N A F \_W \quad \square A T L$.

Fig. 3. Relative scores of the components in UB and RS in relation to the different air mass scenarios; NAF_W: North African air mass from the west; Atl.: Atlantic advection; REG.: regional air circulation; NAF_E: North African from the east over the Mediterranean Sea (Dall Osto et al., 2012a).

17 October, Fig. 2), coinciding with regional recirculation air masses (Fig. 3, 70\%) as well as with the permission to burn litter from fields surrounding the urban area of Barcelona (DOGC, 1995).

Although the relative contribution of BBOA was higher at UB (12\%) than at RS (7\%), both monitoring sites presented roughly similar concentrations (about $0.3 \mu \mathrm{g} \mathrm{m}^{-3}$ ).
Mohr et al. (2012) also found a moderate contribution of $11 \%$ for BBOA in winter 2009 by AMS analysis, which was correlated with off-line filter analysis of levoglucosan (Van Drooge et al., 2012a). The contribution of BBOA was very similar to the $0.4 \mu \mathrm{g} \mathrm{m}^{-3}$ estimated for the UB site after yearround measurements in 2009 (Reche et al., 2012). These contributions are in the lower range of those estimated for other European sites (0.04-3.1 $\mu \mathrm{g} \mathrm{OC} \mathrm{m}{ }^{-3}$; Puxbaum et al., 2007), where the higher concentrations are observed in sites that are directly exposed to local biomass burning. It is important to remember that organic tracers for biomass burning may to be susceptible to oxidation (Hennigan et al., 2011; Hoffmann et al., 2010; Kessler et al., 2010). However, the analysis of inorganic species during the SAPUSS study (Dall'Osto et al., 2013a) also found a similar apportionment at the two monitoring sites, although slightly higher at the UB site.

\subsubsection{Isoprene secondary organic aerosol (SOA ISO)}

$\mathrm{C}_{5}$ alkene triols $(65 \%), 2-\mathrm{MGA}(42 \%)$ and the 2-MTs $(60 \%)$ represent the SOA tracers of isoprene oxidation, and they are grouped in one component that accounts for $11 \%$ of the explained variance. Based on the high NO levels in the city center (Dall'Osto et al., 2013b), one would expect larger differences between the two monitoring sites as seen for some of the isoprene markers (see Sect. 3.1.7). Nevertheless, the overall contributions of SOA ISO were similar at both sites $\left(0.4\right.$ and $0.3 \mu \mathrm{g} \mathrm{m}^{-3}$ at UB and RS, respectively), suggesting mainly a regional origin. Indeed, about $50 \%$ (Fig. 3) of the concentrations detected were recorded during regional air masses, while considerably lower contributions were observed when the air mass came from the Mediterranean Sea. The regional apportionment of the SOA ISO is also reflected in the temporal trend of this component (Fig. 2), which was found to be very similar between the two sites $\left(r^{2}=0.7, P<0.05\right)$.

\subsubsection{Biogenic $\alpha$-pinene secondary organic aerosol (SOA BIO PIN)}

Another component is dominated by a strong signal associated with cis-pinonic acid (72\%), a first-generation product of $\alpha$-pinene oxidation and minor contributions from 2methyltetrols (24\%), succinic acid and glutaric acid (22\%). Hopanes were also found to contribute to this aerosol source ( $35 \%$ of the total hopanes signal) and could be related to biogenic hopanoid precursors produced by microbiota (Yan et al., 2008). Other second-generation products of $\alpha$-pinene oxidation (i.e. 3-hydroxyglutaric acid and MBTCA) did not contribute to this component, implying it is relatively fresh (see Sect. 3.1.6). The SOA BIO PIN component accounted for $10 \%$ of the explained variance, with average concentrations estimated to be $0.5 \mu \mathrm{g} \mathrm{m}^{-3}$ at UB (24\% of OA) and $0.2 \mu \mathrm{g} \mathrm{m}^{-3}$ at RS (7\%), respectively. The temporal trends at both sites were poorly correlated $\left(r^{2}=0.3, P<0.05\right)$, 
suggesting this SOA component did not impact the two monitoring site at the same level. This could be due to different reasons, including the fact that $\alpha$-pinene SOA probably undergoes further oxidation in the city center. This is in contrast to the previous SOA described (SOA ISO) where no difference was found between the two monitoring sites.

The present study shows a remarkable temporal trend (Fig. 2): the highest SOA BIO PIN scores at both monitoring sites were recorded on 5 October 2010, when a strong urban new particle formation (NPF) event was detected (Dall'Osto et al., 2013c). Furthermore, high levels can also be seen on 25-27 September when other minor NPF events were detected. Cis-pinonic acid has been linked to nucleation processes in forested areas as a first step in the formation of aerosols from organic vapors (O'Dowd et al., 2002; Laaksonen et al., 2008). Further considerations on the matter are discussed later in Sect. 4.

\subsubsection{Aged secondary organic aerosol (SOA Aged)}

SOA tracer compounds of both anthropogenic and biogenic origin, including $\mathrm{C}_{3}-\mathrm{C}_{5}$ DCA $(40 \%), \mathrm{C}_{7}-\mathrm{C}_{9}$ DCA $(20 \%)$, phthalic acid (26\%), hydroxy-DCA (45\%) and tricarballytic acid $(75 \%)$, were defining this component. It is interesting to note the absence of cis-pinonic signal, suggesting that this SOA component is more aged than the SOA BIO PIN. Indeed, 3-hydroxyglutaric acid and MBTCA can be seen in this SOA Aged profile (Fig. 2) as products from further photochemical reactions of cis-pinonic acid (Szmigielski et al., 2007). The higher contribution of $\mathrm{C}_{3}-\mathrm{C}_{5}$ DCA over $\mathrm{C}_{7}-\mathrm{C}_{9}$ DCA also indicates the more aged character of this component, since the higher-carbon-numbered DCA tend to photochemically degrade to smaller DCA (Yang et al., 2008b). Further support from the high degree of "aging" of this component also comes from the trend seen for the isoprene SOA markers, with the 2-MGA score being the strongest among all isoprene markers. In other words, when comparing this SOA Aged component with the SOA ISO one (Fig. 2), whilst 2-MGA is found to be the least important tracer among the four main ones describing this component, the opposite trend is seen for SOA Aged. Interestingly, the SOA Aged component shows the best correlation $\left(r^{2}=0.6\right)$ with the OOA component from preliminary AMS-PMF analysis among all other components.

This component accounted for $18 \%$ of the explained variance and was related to SOA tracers. Similar concentrations $\left(0.4 \mu \mathrm{g} \mathrm{m}^{-3} \mathrm{OC}\right)$ were found at both sites $(18 \%$ of OA at UB; $12 \%$ at RS). There was a good correlation between the scores of the two sampling sites $\left(r^{2}=0.5\right)$, suggesting this SOA component is impacting the two sites at a similar level. The temporal trend of this component (Fig. 2) was air mass dependent, with lowest values observed during windy North Atlantic advections (Fig. 3).

\subsubsection{Oxidized organic aerosol of mainly urban origin (OOA Urban)}

Contrary to the previously described five OA sources, it is not known at this stage if this OOA Urban source has a primary and/or a secondary component; hence the name does not include any specification in this regard. The unique feature of this aerosol source is the strong association with pimelic $(65 \%)$, suberic $(61 \%)$ and azelaic $(55 \%)$ acids $\left(\mathrm{C}_{7-}\right.$ $\left.\mathrm{C}_{9} \mathrm{DCA}\right)$. It is also interesting to note the presence of PAHs ( $21 \%$ of total PAH signal), with particular evidence for coronene (39\%, strongest signal of all six sources) and minor ones from benzo[ghi]perylene (32\%) and benz[a]anthracene $(33 \%)$. This source has also the peculiarity of containing the remaining $20 \%$ of the nicotine signal, which in this study is mainly apportioned by POA Urban $(80 \%$; see Sect. 3.2.1 and Fig. 2). OOA Urban was found to have an average concentration of $0.8 \mu \mathrm{g} \mathrm{m}^{-3}(23 \%)$ at the RS site and of $0.2 \mu \mathrm{g} \mathrm{m}^{-3}$ $(10 \%)$ at the UB site. A temporal correlation of this OA source was not found between the two monitoring sites. The consistently higher abundance of this component at the city center site (RS) with respect to the urban background site (UB), as well as a daytime maximum (Fig. 2), suggest that local urban emissions sources were involved. The strong PAH_high component (benzo[ghi]pyrene and coronene) suggests that motor vehicle emissions, previously associated mainly with primary gasoline-powered vehicles, could be involved (Rogge et al., 1993; Zielinska et al., 2004). On the other hand, $\mathrm{C}_{7}-\mathrm{C}_{9}$ DCAs are often associated with oxidation of unsaturated fatty acids (e.g. oleic acid; Moise et al., 2002). A major source for primary emissions of oleic acid in an urban environment is food cooking (Schauer et al., 2002; Robinson et al., 2006b), so this source could also be related to the one reported by Mohr et al. (2012), attributing $17 \%$ of the atmospheric organic $\mathrm{PM}_{1}$ due to primary food cooking emissions in the same location. The OOA Urban component was found to correlate only moderately with preliminary PMF results from the HR-ToF-AMS analysis. A weak correlation with cooking organic aerosol (COA, $\left.r^{2}=0.45\right)$ was found only at the RS but not at the UB site, suggesting that OOA Urban is a mixture of urban sources.

Nevertheless, a complex air mass dependency of this source at both monitoring sites suggests that this component is also related to atmospheric processes. Figure 3 shows that at both sites the higher scores of OOA Urban were observed under North African air masses from the Mediterranean Sea (NAF_East, with maximum at both monitoring sites between 7 and 10 October, Fig. 2). During this period, the concentrations at the two monitoring sites were highly correlated $\left(r^{2}=0.9\right)$ and the increase of the OOA Urban coincided with the increase of SOA Aged. However, in two other REG. periods of elevated SOA Aged concentrations (29 September-3 October and 14-17 October) the OOA Urban component was found at relatively low concentrations and not correlated between the two monitoring sites. Whilst during NAF_East air 


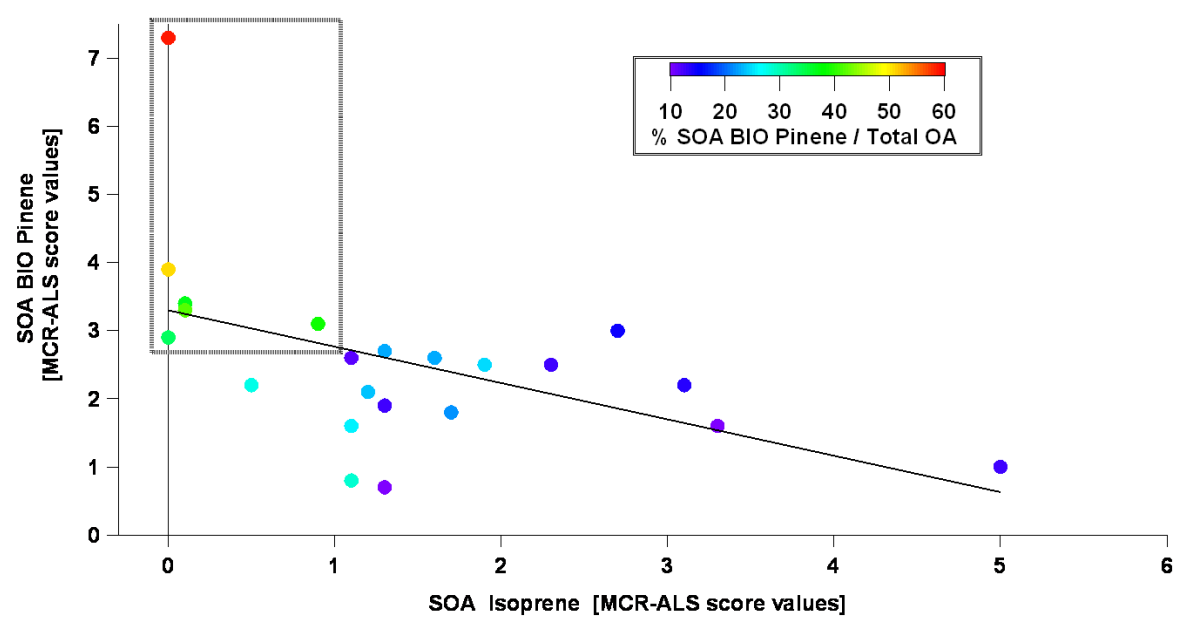

Fig. 4. MCR-ALS scores values for SOA isoprene and SOA BIO pinene for daytime samples (09:00-21:00) collected during SAPUSS. Please note the rectangle in figure includes the five nucleation days seen during SAPUSS (25, 26, 27 September, 5 and 18 October 2010$).$

mass type the nitrate concentrations were at minimum, the opposite scenarios was found for the REG. air mass types (Dall'Osto et al., 2013a). Yang et al. (2008b) previously reported that the nitrate ions play a major role in accelerating the photo-oxidation of azelaic acid by increasing $\mathrm{OH}$ concentration. This could be a possible explanation of why OOA Urban can accumulate during "sulphate high-nitrate low" air masses (NAF_East) whereas much lower concentrations are found during "sulphate low-nitrate high" air masses (REG.) at both sites.

In summary, it seems that certain atmospheric conditions are responsible for the abundance of OOA Urban OA source. This aerosol component is the least characterized of the six ones apportioned in this study. It points to compounds related to gasoline vehicle emissions and cooking activities, and the different behaviors under different air masses suggest its abundance depend on the atmospheric conditions encountered during its emission.

\section{Implications and conclusions}

The application of MCR-ALS on a database generated from off-line GC-MS analysis of 36 organic tracer compounds in $103 \mathrm{PM}_{1}$ filter samples collected simultaneously in two sites from Barcelona during 30 successive days allowed the identification of six organic aerosol components in the two sites that explained $96 \%$ of the total database variance. The specific study of these components provides information on the environmental sources and processes responsible for the organic aerosol constituents.

Two of the aerosol components (POA Urban and BBOA REG.) could be linked directly to primary anthropogenic emission sources. At the RS site, the primary emissions from anthropogenic sources explain $43 \%$ of the variance of the
OA, whereas only $28 \%$ at the UB site. Overall, the regional BBOA component had little influence on the air quality in the city.

The sum of the three SOA components (SOA Aged, SOA ISO and SOA BIO PIN) contributed $60 \%$ of the OA at the UB, in line with the $55 \%$ calculated by Mohr et al. (2012) in the same location during winter 2009. The relatively high contribution of SOA in the urban background of Barcelona is related to the high frequency of anticyclonic weather conditions, allowing aged aerosols to accumulate. At the RS, the SOA component was found to be only $27 \%$. Two of them were represented by products of isoprene and $\alpha$-pinene oxidation, while the third was composted by a mixture of more oxidized compounds from anthropogenic and biogenic origin. Most of the SOA formed from biogenic sources are believed to be due to isoprene and monoterpene emissions because of their high emission rates from various vegetated surfaces. Biogenic contributions to SOA were previously expected to be relatively low in urban areas. However, the complex emissions in urban settings have been shown to accelerate oxidation of biogenic VOCs and thus production of biogenic SOA (Goldstein and Galbally, 2007; Liao et al., 2007). Our study suggests that the overall biogenic SOA component at the UB and RS was at least $42 \%$ and $15 \%$, respectively, with a ISO / PIN ratio of about 3 .

An unexpected sticking result of this work is the relationship between SOA ISO, SOA BIO PIN and the NPF events during the SAPUSS project. Briefly, a clustering analysis of aerosol size distributions data collected at a UB site in Barcelona revealed that ultrafine particles often fail to grow above $10 \mathrm{~nm}$ (Dall'Osto et al., 2012). However, NPF originating within the city center can growth to larger sizes while being transported away from the city to the urbanregional background (Dall'Osto et al., 2013c). Previous laboratory results showed that the high reactivity of isoprene 
with $\mathrm{OH}$ leads to suppression of new particle formation (Kiendler-Scharr et al., 2009). Large isoprene emissions can also suppress NPF formation in forests although the underlying mechanism for the suppression is unclear (Kanawade et al., 2011). Although the role of biogenic VOC in limiting oxidant levels is established, the influence of $\mathrm{OH}$ remains uncertain (Taraborrelli et al., 2012).

Figure 4 summarizes a key finding of our study during the SAPUSS project. A clear anti correlation between SOA ISO and SOA BIO PIN can be seen for the plotted $\mathrm{PM}_{1}$ daytime samples. Additionally, the five days characterized by NPF events are all distributed in the top left part of the panel. In other words, our results suggest that large isoprene emissions can suppress NPF formation in urban areas. Furthermore, the very high percentages of SOA BIO PIN in the $\mathrm{PM}_{1}$ mass detected during the NPF events suggest that biogenic compounds could be partially responsible for the growth of ultrafine particles in the urban area of Barcelona. Such results go in the same direction of recent findings in the same area showing that the majority of OA is of non-fossil origin (Minguillón et al., 2011).

The third SOA component (SOA Aged) contains a mixture of both biogenic and anthropogenic SOA tracers. Therefore, it was not possible to estimate the contribution of non-fossil and fossil organic carbon in this component. By considering BBOA REG., SOA BIO PIN of non-fossil origin, this was about $37 \%$ at the $\mathrm{UB}\left(0.8 \mu \mathrm{g} \mathrm{m}^{-3}\right)$ and $15 \%$ at the RS $\left(0.5 \mu \mathrm{g} \mathrm{m}^{-3}\right)$. It is likely that SOA ISO is mainly biogenic during the studied period although a possible influence of an anthropogenic contribution in the urban sites could not be excluded. Nevertheless, adding SOA ISO to the non-fossil OA would lead to contributions of $54 \%$ and $22 \%$ at UB and RS, respectively. The relatively large contribution of non-fossil SOA in this study is in agreement with the isotopic carbon data from former studies in the same urban area (Minguillón et al., 2011).

What remains unclear in the present study is the exact meaning of the OOA Urban component. It is composed mainly of $\mathrm{C}_{7}-\mathrm{C}_{9}$ dicarboxylic acids, with contributions of $\mathrm{PAH}$ high compounds. Our results suggest that the presence of this aerosol source of anthropogenic origin depends on a number of unknown conditions. When analyzing the MCRALS seven-component solution (see Supplement), two new components appear. POA Urban 1 (PAH_high and nicotine) and POA Urban 2 (PAH_low and hopanes) somehow take away all the primary OA component from OOA Urban, leaving it with only the $\mathrm{C}_{7}-\mathrm{C}_{9}$ signature (Fig. S1). Unfortunately, the solution with seven components worsens all other external correlations with all the other existing factors, and therefore it cannot be chosen as the correct one. Nevertheless, this suggests that both POA Urban and OOA Urban somehow hide some unknown OA sources or processes not distinguishable in this study. The $12 \mathrm{~h}$ sampling time resolution used in this study does not allow us to fully apportion OOA Urban to traffic or cooking emissions. Although the linkage of this component to traffic cannot be excluded, the chemical composition formed by the $\mathrm{C}_{7}-\mathrm{C}_{9}$ dicarboxylic acids suggests that cooking activities could play an important role in this component. Nevertheless, the component is represented only by the less volatile products of the oxidation of unsaturated fatty acids (Moise and Rudich, 2002). The air mass dependence of the component indicates that its abundance cannot be directly linked to any emission source, but could be related to oxidation processes in the urban center.

This study reveals that $43-66 \%$ and $18-28 \%$ of the OA detected at the RS and UB, respectively, have an urban origin, leaving a substantial contribution of biogenic components in the studied urban area. However, the urban atmosphere seems to be responsible for the transformation of OA (Donahue et al., 2009), creating difficulties in fully assigning OA sources with the traditional definitions of primary and secondary organic aerosol. In future publications of this ACP special issue, data from collocated and independent SAPUSS measurements will be compared with the apportionment of the OA sources obtained during this study (GC-MS/MCR-ALS), in order to increase the insights of the potential sources and transformation processes in the urban Mediterranean area of Barcelona.

Acknowledgements. Technical assistance from R. Chaler and D. Fanjul is acknowledged. Financial support for this study was provided by the Marie Curie FP7 SAPUSS (FP7-PEOPLE2009-IEF, Project number 254773), and previously supported by research projects from the D. G. de Calidad y Evaluacion Ambiental (Spanish Ministry of the Environment) and the Plan Nacional de IyD (Spanish Ministry of Science and Innovation) CGL2010-19464-VAMOS, CTQ2009-11572 and CTQ2009-37714777-C02-01-AERTRANS). The SAPUSS team is acknowledged.

Edited by: A. S. H. Prevot

\section{References}

Allan, J. D., Williams, P. I., Morgan, W. T., Martin, C. L., Flynn, M. J., Lee, J., Nemitz, E., Phillips, G. J., Gallagher, M. W., and Coe, H.: Contributions from transport, solid fuel burning and cooking to primary organic aerosols in two UK cities, Atmos. Chem. Phys., 10, 647-668, doi:10.5194/acp-10-647-2010, 2010.

Bahreini, R., Middlebrook, A. M., De Gouw, J. A., Warneke, C., Trainer, M., Brock, C. A., Stark, H., Brown, S. S., Dube, W. P., Gilman, J. B., Hall, K., Holloway, J. S., Kuster, W. C., Perring, A. E., Prevot, A. S. H., Schwarz, J. P., Spackman, J. R., Szidat, S., Wagner, N. L., Weber, R. J., Zotter, P., and Parrish, D. D.: Gasoline emissions dominate over diesel in formation of secondary organic aerosol mass, Geophys. Res. Lett., 39, L06805, doi:10.1029/2011GL050718, 2012.

Bi, X., Sheng, G., Feng, Y., Fu, J., and Xie, J.: Gas- and particulatephase specific tracer and toxic organic compounds in environmental tobacco smoke, Chemosphere, 61, 1512-1522, 2005. 
Bi, X., Simoneit, B. R. T., Sheng, G., Ma, S., and Fu, J.: Composition and major sources of organic compounds in urban aerosols, Atmos. Res., 88, 256-265, 2008.

Borbon, A., Fontaine, H., Veillerot, M., Locoge, N., Galloo, J. C., and Guillermo, R.: An investigation into traffic-related fraction of isoprene at an urban location, Atmos. Environ., 35, 37493760, 2001.

Brunekreef, B.: Forsberg, B.: Epidemiological evidence of effects of coarse airbone particles on health, Eur. Respir. J., 26, 309318, 2005.

Canagaratna, M. R., Jayne, J. T., Jimenez, J. L., Allan, J. D., Alfarra, M. R., Zhang, Q., Onasch, T. B., Drewnick, F., Coe, H., Middlebrook, A., Delia, A., Williams, L. R., Trimborn, A. M., Northway, M. J., DeCarlo, P. F., Kolb, C. E., Davidovits, P., and Worsnop, D. R.: Chemical and microphysical characterization of ambient aerosols with the aerodyne aerosol mass spectrometer, Mass Spectrom. Rev., 26, 185-222, 2007.

Claeys, M., Graham, B., Vas, G., Wang, W., Vermeylen, R., Pashynska, V., Cafmeyer, J., Guyon, P., Andrae, M. O., Artaxo, P., and Maenhaut, W.: Formation of secondary organic aerosols through photooxidation of isoprene, Science, 303, 1173-1176, 2004.

Claeys, M., Szmigielski, R., Kourtchev, I., Van der Veken, P., Vermeylen, R., Maenhaut, W., Jaoui, M., Kleindienst, T., Lewandowski, M., Offenberg, J., and Edney, E.: Hydroxydicarboxylic Acids: Markers for Secondary Organic Aerosol from the Photooxidation of $\alpha$-Pinene, Environ. Sci. Technol., 41, 16281634, 2007.

Clements, A. L. and Seinfeld, J. H.: Detection and quantification of 2-methyltetrols in ambient aerosol in the southeastern United States, Atmos. Environ., 41, 1825-1830, 2007.

Dall'Osto, M., Beddows, D. C. S., Pey, J., Rodriguez, S., Alastuey, A., Harrison, R. M., and Querol, X.: Urban aerosol size distributions over the Mediterranean city of Barcelona, NE Spain, Atmos. Chem. Phys., 12, 10693-10707, doi:10.5194/acp-1210693-2012, 2012.

Dall'Osto, M., Querol, X., Amato, F., Karanasiou, A., Lucarelli, F., Nava, S., Calzolai, G., and Chiari, M.: Hourly elemental concentrations in $\mathrm{PM}_{2.5}$ aerosols sampled simultaneously at urban background and road site during SAPUSS - diurnal variations and PMF receptor modelling, Atmos. Chem. Phys., 13, 43754392, doi:10.5194/acp-13-4375-2013, 2013a.

Dall'Osto, M., Querol, X., Alastuey, A., Minguillon, M. C., Alier, M., Amato, F., Brines, M., Cusack, M., Grimalt, J. O., Karanasiou, A., Moreno, T., Pandolfi, M., Pey, J., Reche, C., Ripoll, A., Tauler, R., Van Drooge, B. L., Viana, M., Harrison, R. M., Gietl, J., Beddows, D., Bloss, W., O’Dowd, C., Ceburnis, D., Martucci, G., Ng, N. L., Worsnop, D., Wenger, J., Mc Gillicuddy, E., Sodeau, J., Healy, R., Lucarelli, F., Nava, S., Jimenez, J. L., Gomez Moreno, F., Artinano, B., Prévôt, A. S. H., Pfaffenberger, L., Frey, S., Wilsenack, F., Casabona, D., Jiménez-Guerrero, P., Gross, D., and Cots, N.: Presenting SAPUSS: Solving Aerosol Problem by Using Synergistic Strategies in Barcelona, Spain, Atmos. Chem. Phys., 13, 8991-9019, doi:10.5194/acp-13-89912013, 2013b.

Dall'Osto, M., Querol, X., Alastuey, A., O’Dowd, C., Harrison, R. M., Wenger, J., and Gómez-Moreno, F. J.: On the spatial distribution and evolution of ultrafine particles in Barcelona, Atmos. Chem. Phys., 13, 741-759, doi:10.5194/acp-13-741-2013, 2013c.
Ding, X., Wang, X.-M., and Zheng, M.: The influence of temperature and aerosol acidity on biogenic secondary organic aerosol tracers: observations at a rural site in the central Pearl River Delta region, South China, Atmos. Environ., 45, 1303-1311, 2011.

DOGC 1995: Forest fire prevention, Catalunya, Ordinance 64/1995.

Donahue, N. M., Robinson, A. L., and Pandis, S. N.: Atmospheric organic particulate matter: From smoke to secondary organic aerosol, Atmos. Environ., 43, 94-106, 2009.

Edney, E. O., Kleindienst, T. E., Jaoui, M., Lewandowski, M., Offenberg, J. H., Wang, W., and Cleays, M.: Formation of 2methyltetrols and 2-methylglyceric acid in secondary aerosol from laboratory irradiated isoprene/NOx/SO2/air mixture and their detection in ambient air $\mathrm{PM}_{2.5}$ samples collected in the eastern United States, Atmos. Environ., 39, 5281-5289, 2005.

El Haddad, I., Marchand, N., Temime-Roussel, B., Wortham, H., Piot, C., Besombes, J.-L., Baduel, C., Voisin, D., Armengaud, A., and Jaffrezo, J.-L.: Insights into the secondary fraction of the organic aerosol in a Mediterranean urban area: Marseille, Atmos. Chem. Phys., 11, 2059-2079, doi:10.5194/acp-11-20592011, 2011.

Fang, J., Kawamura, K., Ishimura, Y., and Matsumoto, K.: Carbon isotope composition of fatty acids in the marine aerosols from the Western North Pacific: Implication for the source and atmospheric transport, Environ. Sci. Technol., 62, 2598-2604, 2002.

Filella, I. and Penuelas, J.: Daily, weekly, and seasonal time courses of VOC concentrations in a semi-urban area near Barcelona, Atmos. Environ., 40, 7752-7769, 2006

Fine, P. M., Cass, G. R., and Simoneit, B. R. T.: Chemical characterization of fine particle emissions from the fireplace combustion of wood types grown in the Midwestern and Western United States, Environ. Eng. Sci., 21, 387-409, 2004.

Forster, P., Ramaswamy, V., Artaxo, P., Berntsen, T., Betts, R., Fahey, D. W., Haywood, J., Lean, J., Lowe, D. C., Myhre, G., Nganga, J., Prinn, R., Raga, G., Schulz, M., and Van Dorland, R.: Changes in Atmospheric Constituents and in Radiative Forcing. In: IPCC, Climate Change 2007: The Physical Science Base. Contribution of Working Group I to the fourth Assessment Report of the IPCC, ISBN: 9780521 88009-1, 2007.

Galarneau, E. Source specificity and atmospheric processing of airborne PAHs: Implications for source apportionment, Atmos. Environ., 42, 8139-8149, 2008.

Gogou, A., Stephanou, E. G., Stratigakis, N., Grimalt, J. O., Simo, R., Aceves, M., and Albaiges, J.: Differences in lipid and organic salt constituents of aerosols from Eastern and Western Mediterranean coastal cities, Atmos. Environ., 28, 1301-1310, 1994.

Goldstein, A. H. and Galbally, I. E.: Known and unexplored organic constituents in the earth's atmosphere, Environ. Sci. Technol., 41, 1514-1521, 2007.

Grieshop, A. P., Donahue, N. M., and Robinson, A. L.: Laboratory investigation of photochemical oxidation of organic aerosol from wood fires 2: analysis of aerosol mass spectrometer data, Atmos. Chem. Phys., 9, 2227-2240, doi:10.5194/acp-9-2227-2009, 2009.

Guenther, A., Hewitt, C. N., Erickson, D., Fall, R., Geron, C., Graedel, T., Harley, P., Klinger, L., Lerdau, M., Mckay, W. A Pierce, T., Scholes, B., Steinbrecher, R., Tallamraju, R., Taylor, J., and Zimmerman, P.: A Global-Model of Natural Volatile Organic-Compound Emissions, J. Geophys. Res., 100, 88738892, 1995. 
Hallquist, M., Wenger, J. C., Baltensperger, U., Rudich, Y., Simpson, D., Claeys, M., Dommen, J., Donahue, N. M., George, C., Goldstein, A. H., Hamilton, J. F., Herrmann, H., Hoffmann, T., Iinuma, Y., Jang, M., Jenkin, M. E., Jimenez, J. L., Kiendler-Scharr, A., Maenhaut, W., McFiggans, G., Mentel, Th. F., Monod, A., Prévôt, A. S. H., Seinfeld, J. H., Surratt, J. D., Szmigielski, R., and Wildt, J.: The formation, properties and impact of secondary organic aerosol: current and emerging issues, Atmos. Chem. Phys., 9, 5155-5236, doi:10.5194/acp-9-51552009, 2009.

Heald, C. L., Kroll, J. H., Jimenez, J. L., Docherty, K. S., DeCarlo, P. F., Aiken, A. C., Chen, Q., Martin, S. T., Farmer, D. K., Artaxo, P., and Weinheimer, A. J.: A simplified description of organic aerosol composition and implications for atmospheric aging, Geophys. Res. Lett., 37, 8, L08803, doi:10.1029/2010GL042737, 2010.

Hennigan, C. J., Miracolo, M. A., Engelhart, G. J., May, A. A., Presto, A. A., Lee, T., Sullivan, A. P., McMeeking, G. R., Coe, H., Wold, C. E., Hao, W.-M., Gilman, J. B., Kuster, W. C., de Gouw, J., Schichtel, B. A., J. L. Collett Jr., Kreidenweis, S. M., and Robinson, A. L.: Chemical and physical transformations of organic aerosol from the photo-oxidation of open biomass burning emissions in an environmental chamber, Atmos. Chem. Phys., 11, 7669-7686, doi:10.5194/acp-11-7669-2011, 2011.

Ho, K. F., Ho, S. S. H., Lee, S. C., Kawamura, K., Zou, S. C., Cao, J. J., and $\mathrm{Xu}, \mathrm{H}$. M.: Summer and winter variations of dicarboxylic acids, fatty acids and benzoic acid in $\mathrm{PM}_{2.5}$ in Pearl Delta River Region, China, Atmos. Chem. Phys., 11, 2197-2208, doi:10.5194/acp-11-2197-2011, 2011.

Hoffmann, D., Tilgner, A., Iinuma, Y., and Herrmann, H.: Atmospheric stability of levoglucosan: A detailed laboratory and modeling study, Environ. Sci. Technol., 44, 694-699, 2010.

Ion, A. C., Vermeylen, R., Kourtchev, I., Cafmeyer, J., Chi, X., Gelencsér, A., Maenhaut, W., and Claeys, M.: Polar organic compounds in rural $\mathrm{PM}_{2.5}$ aerosols from K-puszta, Hungary, during a 2003 summer field campaign: Sources and diel variations, Atmos. Chem. Phys., 5, 1805-1814, doi:10.5194/acp-5-1805-2005, 2005.

Jang, M. and McDow, S. R.: Products of benz[a]anthrancene photodegradation in the presence of known organic constituents of atmospheric aerosols, Environ. Sci. Technol., 31, 1046-1053, 1997.

Jaumot, J., Gargallo, R., de Juan, A., and Tauler, R.: A graphical user-friendly interface for MCR-ALS: a new tool for multivariate curve resolution in MATLaboratory, Chemometr. Intell. Lab., 76, 101-110, 2005.

Jimenez, J. L., Canagaratna, M. R., Donahue, N. M., Prevot, A. S. H., Zhang, Q., Kroll, J. H., DeCarlo, P. F., Allan, J. D., Coe, H., Ng, N. L., Aiken, A. C., Docherty, K. S., Ulbrich, I. M., Grieshop, A. P., Robinson, A. L., Duplissy, J., Smith, J. D., Wilson, K. R., Lanz, V. A., Hueglin, C., Sun, Y. L., Tian, J., Laaksonen, A., Raatikainen, T., Rautiainen, J., Vaattovaara, P., Ehn, M., Kulmala, M., Tomlinson, J. M., Collins, D. R., Cubison, M. J., Dunlea, J., Huffman, J. A., Onasch, T. B., Alfarra, M. R., Williams, P. I., Bower, K., Kondo, Y., Schneider, J., Drewnick, F., Borrmann, S., Weimer, S., Demerjian, K., Salcedo, D., Cottrell, L., Griffin, R., Takami, A., Miyoshi, T., Hatakeyama, S., Shimono, A., Sun, J. Y., Zhang, Y. M., Dzepina, K., Kimmel, J. R., Sueper, D., Jayne, J. T., Herndon, S. C., Trimborn, A. M.,
Williams, L. R., Wood, E. C., Middlebrook, A. M., Kolb, C. E., Baltensperger, U., and Worsnop, D. R: Evolution of organic aerosols in the atmosphere, Science, 326, 1525-1529, 2009.

Jolliffe, I. T.: Principal Component Analysis, 2nd ed., SpringerVerlag, New York, USA, 2002.

Kanakidou, M., Seinfeld, J. H., Pandis, S. N., Barnes, I., Dentener, F. J., Facchini, M. C., Van Dingenen, R., Ervens, B., Nenes, A., Nielsen, C. J., Swietlicki, E., Putaud, J. P., Balkanski, Y., Fuzzi, S., Horth, J., Moortgat, G. K., Winterhalter, R., Myhre, C. E. L., Tsigaridis, K., Vignati, E., Stephanou, E. G., and Wilson, J.: Organic aerosol and global climate modelling: a review, Atmos. Chem. Phys., 5, 1053-1123, doi:10.5194/acp-5-1053-2005, 2005.

Kanawade, V. P., Jobson, B. T., Guenther, A. B., Erupe, M. E., Pressley, S. N., Tripathi, S. N., and Lee, S.-H.: Isoprene suppression of new particle formation in a mixed deciduous forest, Atmos. Chem. Phys., 11, 6013-6027, doi:10.5194/acp-11-60132011, 2011.

Kawamura, K. and Gagosian, R. B.: Implications of $\omega$ Oxocarboxylic acids in the remote marine atmosphere for photoOxidation of unsaturated fatty acids, Nature, 325, 330-332, 1987.

Kerminen, V. M., Virkkula, A., Hillamo, R., Wexler, A. S., and Kulmala, M.: Secondary organics and atmospheric cloud condensation nuclei production, J. Geophys. Res., 105, 9255-9264, 2000.

Kessler, S. H., Smith, J. D., Che, D. L., Worsnop, D. R., Wilson, K. R., and Kroll, J. H.: Chemical sinks of organic aerosol: Kinetics and products of the heterogeneous oxidation of erythritol and levoglucosan, Environ. Sci. Technol., 44, 7005-7010, 2010.

Kiendler-Scharr, A., Wildt, J., Dal Maso, M., Hohaus, T., Kleist, E., Mentel, T. F., Tillmann, R., Uerlings, R., Schurr, U., and Wahner, A.: New particle formation in forests inhibited by isoprene emissions, Nature, 461, 381-384, 2009.

Kourtchev, I., Ruuskanen, T., Maenhaut, W., Kulmala, M., and Claeys, M.: Observation of 2-methyltetrols and related photo-oxidation products of isoprene in boreal forest aerosols from Hyytiälä, Finland, Atmos. Chem. Phys., 5, 2761-2770, doi:10.5194/acp-5-2761-2005, 2005.

Křumal, K., Milkuška, P., and Večeřa, Z.: Polycyclic aromatic hydrocarbons and hopanes in PM1 aerosols in urban areas, Atmos. Environ., 67, 27-37, 2013.

Kubatova, A., Vermeylen, R., Claeys, M., Cafmeyer, J., Maenhaut, W., Roberts, G., and Artaxo, P.: Carbonaceous aerosol characterization in the Amazon basin, Brazil: novel dicarboxylic acids and related compounds, Atmos. Environ., 34, 5037-5051, 2000.

Laaksonen, A., Kulmala, M., O’Dowd, C. D., Joutsensaari, J., Vaattovaara, P., Mikkonen, S., Lehtinen, K. E. J., Sogacheva, L., Dal Maso, M., Aalto, P., Petäjä, T., Sogachev, A., Yoon, Y. J., Lihavainen, H., Nilsson, D., Facchini, M. C., Cavalli, F., Fuzzi, S., Hoffmann, T., Arnold, F., Hanke, M., Sellegri, K., Umann, B., Junkermann, W., Coe, H., Allan, J. D., Alfarra, M. R., Worsnop, D. R., Riekkola, M.-L., Hyötyläinen, T., and Viisanen, Y.: The role of VOC oxidation products in continental new particle formation, Atmos. Chem. Phys., 8, 2657-2665, doi:10.5194/acp-82657-2008, 2008.

Lambe, A. T., Miracolo, M. A., Hennigan, C. J., Robinson, A. L., and Donahue, N. M.: Effective rate constants and uptake coefficients for the reactions of organic molecular markers (nalkanes, hopanes, and steranes) in motor oil and diesel primary 
organic aerosols with hydroxyl radicals, Environ. Sci. Technol., 43, 8794-8800, 2009.

Langford, B., Nemitz, E., House, E., Phillips, G. J., Famulari, D., Davison, B., Hopkins, J. R., Lewis, A. C., and Hewitt, C. N.: Fluxes and concentrations of volatile organic compounds above central London, UK, Atmos. Chem. Phys., 10, 627-645, doi:10.5194/acp-10-627-2010, 2010.

Liao, H., Henze, D. K., Seinfeld, J. H., Wu, S., and Mickley, L. J.: Biogenic secondary organic aerosol over the United States: Comparison of climatological simulations with observations, J. Geophys. Res., 112, D06201, doi:10.1029/2006JD007813, 2007.

Lin, Y.-H., Zhang, Z., Docherty, K. S., Zhang, H., Budisulistiorini, S. H., Rubitschun, C. L., Shaw, S. L., Knipping, E. M., Edgerton, E. S., Kleindienst, T. E., Gold, A., and Surratt, J. D.: Isoprene epoxydiols as precursors to secondary organic aerosol formation: Acid-catalyzed reactive uptake studies with authentic compounds. Environ. Sci. Technol., 46, 250-258, 2012.

Lin, Y.-H., Zhang, H., Pye, H. O. T., Zhang, Z., Marth, W. J., Park, S., Arashiro, M., Cui, T., Budisulistiorini, S. H., Sexton, K. G., Vizuete, W., Xie, Y., Luecken, D. J., Piletic, I. R., Edney, E. O., Bartolotti, L. J., Gold, A., and Surratt, J. D.: Epoxide as a precursor to secondary organic aerosol formation from isoprene photooxidation in the presence of nitrogen oxides, Proc. Natl. Acad. Sci. USA, 110, 6718-6723, 2013.

Lohmann, R. and Lammel, G.: Adsorptive and absorptive contributions to the gas-particle partitioning of polycyclic aromatic hydrocarbons: State of knowledge and recommended parametrization for modeling, Environ. Sci. Technol., 38, 3793-3803, 2004.

Medeiros, P. M. and Simoneit, B. R. T.: Analysis of sugars in environmental samples by gas chromatography-mass spectrometry, J. Chromatogr. A, 1141, 271-278, 2007.

Minguilón, M. C., Perron, N., Querol, X., Szidat, S., Fahrni, S. M., Alastuey, A., Jimenez, J. L., Mohr, C., Ortega, A. M., Day, D. A., Lanz, V. A., Wacker, L., Reche, C., Cusack, M., Amato, F., Kiss, G., Hoffer, A., Decesari, S., Moretti, F., Hillamo, R., Teinilä, K., Seco, R., Peñuelas, J., Metzger, A., Schallhart, S., Müller, M., Hansel, A., Burkhart, J. F., Baltensperger, U., and Prévôt, A. S. H.: Fossil versus contemporary sources of fine elemental and organic carbonaceous particulate matter during the DAURE campaign in Northeast Spain, Atmos. Chem. Phys., 11, 1206712084, doi:10.5194/acp-11-12067-2011, 2011.

Mochida, M., Kawabata, A., Kawamura, K., Hatsushika, H., and Yamazaki, K.: Seasonal variation and origins of dicarboxylic acids in the marine atmosphere over the western North Pacific, J. Geophys. Res.-Atmos., 108, 4193, doi:10.1029/2002JD002355, 2003.

Mohr, C., DeCarlo, P. F., Heringa, M. F., Chirico, R., Slowik, J. G., Richter, R., Reche, C., Alastuey, A., Querol, X., Seco, R., Peñuelas, J., Jiménez, J. L., Crippa, M., Zimmermann, R., Baltensperger, U., and Prévôt, A. S. H.: Identification and quantification of organic aerosol from cooking and other sources in Barcelona using aerosol mass spectrometer data, Atmos. Chem. Phys., 12, 1649-1665, doi:10.5194/acp-12-1649-2012, 2012.

Moise, T. and Rudich, Y.: Reactive Uptake of Ozone by AerosolAssociated Unsaturated Fatty Acids: Kinetics, Mechanism, and Products, J. Phys. Chem. A, 106, 669-6476, 2002.

Ning, Z., Geller, M. D., Moore, K. F., Sheesley, R., Schauer, J. J., and Sioutas, C.: Daily variation in chemical characteristics of ur- ban ultrafine aerosols and inference of their sources, Environ. Sci. Technol., 41, 6000-6006, 2007.

O'Dowd, C. D., Aalto, P., Hämeri, K., Kulmala, M., and Hoffmann, T.: Atmospheric particles from organic vapours, Nature, 416, 497-498, 2002.

Paatero, P. and Tapper, U.: Positive matrix factorization: a nonnegative factor model with optimal utilization of error estimates of data values, Environmetrics, 5, 111-126, 1994.

Paulot, F., Wunch, D., Crounse, J. D., Toon, G. C., Millet, D. B., DeCarlo, P. F., Vigouroux, C., Deutscher, N. M., González Abad, G., Notholt, J., Warneke, T., Hannigan, J. W., Warneke, C., de Gouw, J. A., Dunlea, E. J., De Mazière, M., Griffith, D. W. T., Bernath, P., Jimenez, J. L., and Wennberg, P. O.: Importance of secondary sources in the atmospheric budgets of formic and acetic acids, Atmos. Chem. Phys., 11, 1989-2013, doi:10.5194/acp-11-1989-2011, 2011.

Park, C., Schade, G. W., and Boedeker, I.: Characteristics of the flux of isoprene and its oxidation products in an urban area, J. Geophys. Res.-Atmos., 116, D21303, doi:10.1029/2011JD015856, 2011.

Pérez, N., Pey, J., Cusack, M., Reche, C., Querol, X., Alastuey, A., and Viana, M.: Variability of particle number, black carbon and $\mathrm{PM}_{10}, \mathrm{PM}_{2.5}$ and PM1 levels and speciation: influence of road traffic emissions on urban air quality, Aerosol Sci. Technol., 44, 487-499, 2010.

Pey, J., Querol, X., and Alastuey, A.: Variations of levels and composition of $\mathrm{PM}_{10}$ and $\mathrm{PM}_{2.5}$ at an insular site in the Western Mediterranean, Atmos. Res., 94, 285-299, 2009.

Pratt, K. A. and Prather, K. A.: Mass spectrometry of atmospheric aerosols - Recent developments and applications, Part II: On-line mass spectrometry techniques, Mass Spectrom. Rev., 31, 17-48, 2012.

Puxbaum, H., Caseiro, A., Sánchez-Ochoa, A., Kasper-Giebl, A., Cleays, M., Gelencsér, A., Legrand, M., Preunkert, S., and Pio, C.: Levoglucosan levels at background sites in Europe for assessing the impact of biomass combustion on the European aerosol background, J. Geophys. Res., 112, D23S05, doi:10.1029/2006JD008114, 2007.

Querol, X., Alastuey, A., Moreno, T., Viana, M. M., Castillo, S., Pey, J., Rodríguez, S., Artiñano, B., Salvador, P., Sánchez, M., Garcia Dos Santos, S., Herce Garraleta, M. D., Fernandez-Patier, R., Moreno-Grau, S., Negral, L., Minguillón, M. C., Monfort, E., Sanz, M. J., Palomo-Marín, R., Pinilla-Gil, E., Cuevas, E., de la Rosa, J., and Sánchez de la Campa, A.: Spatial and temporal variations in airborne particulate matter $\left(\mathrm{PM}_{10}\right.$ and $\left.\mathrm{PM}_{2.5}\right)$ across Spain 1999-2005, Atmos. Environ., 42, 3964-3979, 2009.

Reche, C., Moreno, T., Amato, F., Viana, M., van Drooge, B.L., Chuang, H., Bérubé, K., Jones, T., Alastuey, A., and Querol, X.: A multidisciplinary approach to characterise exposure risk and toxicological effects of $\mathrm{PM}_{10}$ and $\mathrm{PM}_{2.5}$ samples in urban environments, Ecotox. Environ. Safe., 78 , 327-335, 2012.

Robinson, A. L., Donahue, N. M., and Rogge, W. F.: Photochemical oxidation and changes in molecular composition of organic aerosol in the regional context, J. Geophys. Res., 111, D03302, doi:10.1029/2005JD006265, 2006a.

Robinson, A. L., Subramanian, R., Donahue, N. M., BernardoBricker, A., and Rogge, W. F.: Source apportionment of molecular markers and organic aerosol -3 . food cooking emissions, Environ. Sci. Technol., 40, 7820-7827, 2006b. 
Robinson, A. L., Donahue, N. M., Shrivastava, M. K., Weitkamp, E. A., Sage, A. M., Grieshop, A. P., Lane, T. E., Pierce, J. R., and Pandis, S. N.: Rethinking organic aerosols: semivolatile emissions and photochemical aging, Science, 315, 1259-1262, 2007.

Rogge, W. F., Hildemann, L. M., Mazurek, M. A., Cass, G. R., and Simoneit, B. R. T.: Sources of fine organic aerosol. 2. Noncatalyst and catalyst-equipped automobiles and heavy duty diesel trucks, Environ. Sci. Technol., 27, 636-651, 1993.

Rogge, W.F., Hildemann, L.M., Marurek, M.A., Glen, R., Cass, G. R., Simoneit, B.R.: Sources of Fine Organic Aerosol. 6. Cigarette Smoke in the Urban Atmosphere, Environ. Sci. Technol., 28, 1375-1388, 1994.

Sage, A. M., Weitkamp, E. A., Robinson, A. L., and Donahue, N. M.: Evolving mass spectra of the oxidized component of organic aerosol: results from aerosol mass spectrometer analyses of aged diesel emissions, Atmos. Chem. Phys., 8, 1139-1152, doi:10.5194/acp-8-1139-2008, 2008.

Salau, J. S. I., Tauler, R., Bayona, J. M., and Tolosa, I.: Input Characterization of Sedimentary Organic Contaminants and Molecular Markers in the Northwestern Mediterranean Sea by Exploratory Data Analysis, Environ. Sci. Technol. 31, 3482-3490, 1997.

Schauer, J. J., Kleemann, M. J., Cass, G. R., and Simoneit, B. R. T.: Measurements of emissions from air pollution sources, 5. C1C32 organic compounds from gasoline-powered motor vehicles, Environ. Sci. Technol., 36, 1169-1180, 2002.

Schauer, J. J., Rogge, W. F., Hildemann, L. M., Mazurek, M. A., and Cass, G. R.: Source apportionment of airborne particulate matter using organic compounds as tracers, Atmos. Environ., 41, S241-S259, 2007.

Schneidemesser, E. V., Monks, P. S., Gros, V., Gauduin, J., and Sanchez, O.: How important is biogenic isoprene in an urban environment? A study in London and Paris, Geophys. Res. Lett., 38, L19804, doi:10.1029/2011GL048647, 2011.

Seco, R., Peñuelas, J., Filella, I., Llusià, J., Molowny-Horas, R., Schallhart, S., Metzger, A., Müller, M., and Hansel, A.: Contrasting winter and summer VOC mixing ratios at a forest site in the Western Mediterranean Basin: the effect of local biogenic emissions, Atmos. Chem. Phys., 11, 13161-13179, doi:10.5194/acp11-13161-2011, 2011.

Seco, R., Peñuelas, J., Filella, I., Llusia, J., Schallhart, S., Metzger, A., Müller, M., and Hansel, A.: Volatile organic compounds in the western Mediterranean basin: urban and rural winter measurements during the DAURE campaign, Atmos. Chem. Phys., 13, 4291-4306, doi:10.5194/acp-13-4291-2013, 2013.

Sheesley, R. J., Deminter, J. T., Meiritz, M., Snyder, D. C., and Schauer, J. J,: Temporal trends in motor vehicle and secondary organic tracers using in situ methylation thermal desorption GCMS, Environ. Sci. Technol., 44, 9398-9404, 2010.

Simoneit, B. R. T.: Biomass burning - a review of organic tracers for smoke from incomplete combustion, Appl. Geochem., 17, 129$162,2002$.

Stanimirova, I., Tauler, R., and Walczak, B.: A Comparison of Positive Matrix Factorization and the Weighted Multivariate Curve Resolution Method. Application to Environmental Data, Environ. Sci. Technol., 45, 10102-10110, 2011.

Stephanou, E. G. and Stratigakis, N.: Oxocarboxylic and alpha,omega-dicarboxylic acids - photooxidation products of biogenic unsaturated fatty-acids present in urban aerosols, Environ. Sci. Technol., 27, 1403-1407, 1993.

Stone, E. A., Zhou, J., Snyder, D. C., Rutter, A. P., Mieritz, M., and Schauer, J. J.: A comparison of summertime secondary organic aerosol source contributions at contrasting urban locations, Environ. Sci. Technol., 43, 3448-3454, 2009.

Subramanian, R., Donahue, N. M., Bernardo-Bricker, A., Rogge, W. F., and Robinson, A. L.: Contribution of motor vehicle emissions to organic carbon and fine particle mass in Pittsburgh, Pennsylvania: Effects of varying source profiles and seasonal trends in ambient marker concentrations, Atmos. Environ., 40, 8002-8019, 2006.

Sureda, X., Martinez-Sanchez, J. M., Lopez, M. J., Fu, M., Aguero, F., Salto, E., Nebot, M., and Fernandez, E: Secondhand smoke levels in public building main entrances: outdoor and indoor $\mathrm{PM}_{2.5}$ assessment, Tobacco Control 21, 543-548, 2012.

Surratt, J. D., Chan, A. W. H., Eddingsaas, N. C., Chan, M. N., Loza, C. L., Kwan, A. L., Hersey, S. P., Flagan, R. C., Wennberg, P. O., and Seinfeld, J. H.: Reactive intermediates revealed in secondary organic aerosol formation from isoprene, P. Natl. Acad. Sci. USA, 107, 6640-6645, 2010.

Szmigielski, R., Surratt, J.D., Gómez-González, Y., Van der Veken, P., Kourtchev, I., Vermeylen, R., Blockhuys, F., Jaoui, M., Kleindienst, T. E., Lewandowski, M., Offenberg, J. H., Edney, E. O., Seinfeld, J. H., Maenhaut, W., and Claeys, M.: 3-Methyl1,2,3-butanetricarboxylic acid: an atmospheric tracer for terpene secondary organic aerosol, Geophys. Res. Lett., 34, L24811, doi:10.1029/2007GL031338, 2007.

Taraborrelli, D., Lawrence, M. G., Crowley, J. N., Dillon, T. J., Gromov, S., Groß, C. B. M., Vereecken, L., and Lelieveld, J.: Hydroxyl radical buffered by isoprene oxidation over tropical forests, Nature Geosci., 5, 190-193, 2012.

Tauler, R.: Multivariate curve resolution applied to second order data, Chemom. Intell. Lab. Syst., 30, 133-146, 1995. 43, 39893997, 2009.

Tauler, R., Smilde, A., and Kowalski, B.: Selectivity, local rank, 3way data-analysis and ambiguity in multivariate curve resolution, J. Chemometr., 9, 31-58, 1995.

Tauler, R., Viana, M., Querol, X., Alastuey, A., Flight, R. M., Wentzell, P. D, and Hopke, P. K.: Comparison of the results obtained by four receptor modelling methods in aerosol source apportionment studies, Atmos. Environ.,

Terrado, M., Barceló, D., and Tauler, R.: Quality assessment of the Multivariate Curve Resolution Alternating Least Squares (MCRALS) method for the investigation of environmental pollution patterns in surface water, Environ. Sci. Technol., 43, 5321-5326, 2009.

US-EPA, Protocol for applying and validating the CMB model (ed. Office for Air Quality Planning and Standards), 1987.

van Drooge, B. L., Crusack, M., Reche, C., Mohr, C., Alastuey, A., Querol, X., Prevot, A., Day, D. A., Jimenez, J. L., and Grimalt, J. O.: Molecular marker characterization of the organic composition of submicron aerosols from Mediterranean urban and rural environments under contrasting meteorological conditions, Atmos. Environ., 61, 482-489, 2012a.

van Drooge, B. L., Lopez, J., and Grimalt, J. O.: Influences of natural emission sources (wildfires and Saharan dust) on the urban organic aerosol in Barcelona (Western Mediterranean Basis) during a PM event, Environ. Sci. Pollut. Res., 19, 4159-4167, 2012b. 
Watson, J. G.: Visibility: Science and regulation, J. AirWaste Manage., 52, 628-713, 2002.

WHO: http://www.who.int/whosis/whostat/EN_WHS10_Full.pdf, last access: December 2010.

Yan, B., Zheng, M., Hu, Y. T., Lee, S., Kim, H. K., and Russell, A. G.: Organic composition of carbonaceous aerosols in an aged prescribed fire plume, Atmos. Chem. Phys., 8, 6381-6394, doi:10.5194/acp-8-6381-2008, 2008.

Yang, L., Ray, M. B., and Yu, L. E.: Photooxidation of dicarboxylic acids - Part II: Kinetics, intermediates and field observations, Atmos. Environ., 42, 868-880, 2008a.

Yang, L., Ray, M. B., and Yu, L. E.: Photooxidation of dicarboxylic acids - Part I: Effects of inorganic ions on degradation of azelaic acid, Atmos. Environ., 42, 856-867, 2008b.
Zhang, Y. Y., Müller, L., Winterhalter, R., Moortgat, G. K., Hoffmann, T., and Pöschl, U.: Seasonal cycle and temperature dependence of pinene oxidation products, dicarboxylic acids and nitrophenols in fine and coarse air particulate matter, Atmos. Chem. Phys., 10, 7859-7873, doi:10.5194/acp-10-7859-2010, 2010.

Zielinska, B., Sagebiel, J., McDonald, J. D., Whitley, K., and Lawson, D. R.: Emission rates and comparative chemical composition from selected in-use diesel and gasoline-fueled vehicles, J. Air Waste Manage. Assoc., 54, 1138-1150, 2004. 